
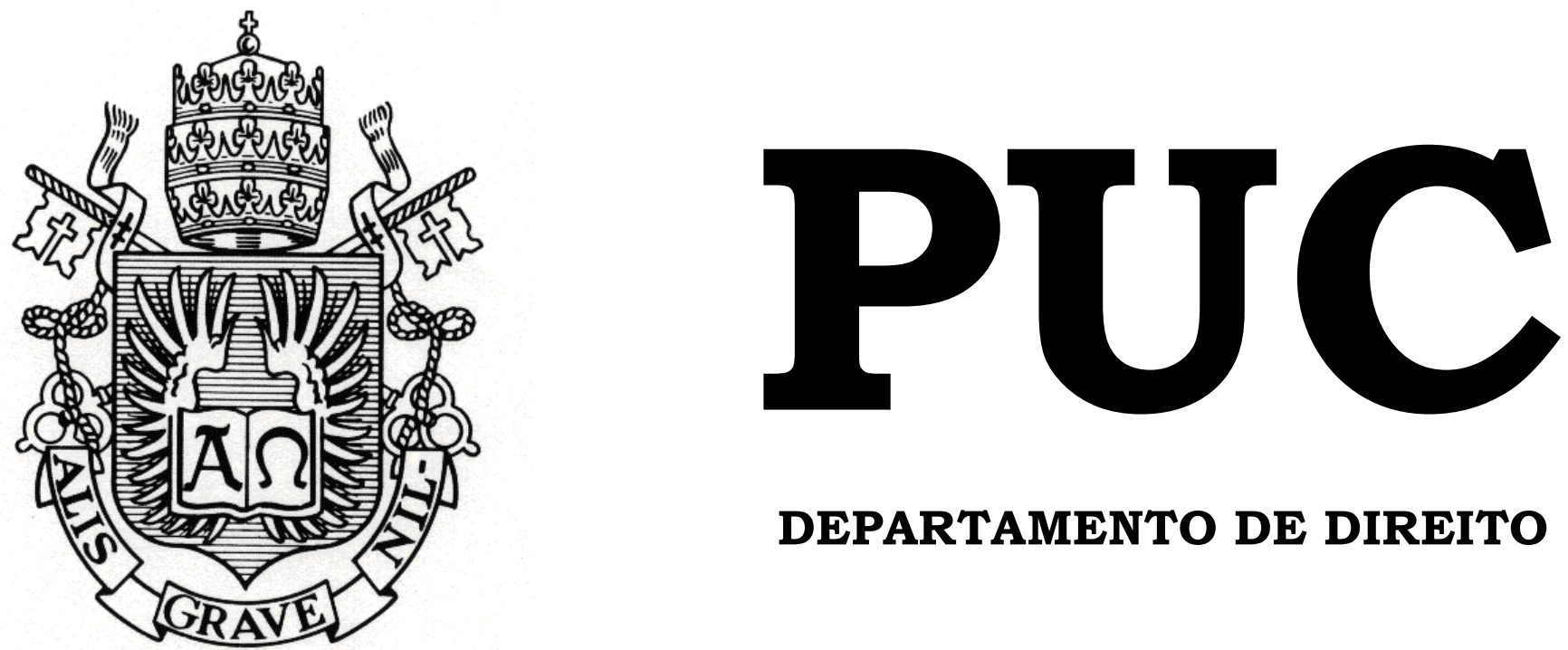

DEPARTAMENTO DE DIREITO

\title{
OS TÍTULOS DE CRÉDITO ELETRÔNICOS E A DUPLICATA VIRTUAL
}

\author{
por \\ LUIZA TOSTES MASCARENHAS BRAGA \\ ORIENTADOR: BRUNO VAZ DE CARVALHO \\ 2009.1
}

PONTIFÍCIA UNIVERSIDADE CATÓLICA DO RIO DE JANEIRO

RUA MARQUÊS DE SÃO VICENTE, 225 - CEP 22453-900

RIO DE JANEIRO - BRASIL 


\title{
OS TÍTULOS DE CRÉDITO ELETRÔNICOS E A DUPLICATA VIRTUAL
}

\author{
por \\ LUIZA TOSTES MASCARENHAS BRAGA
}

Monografia apresentada ao

Departamento de Direito da Pontificia Universidade Católica do Rio de Janeiro (PUC-Rio) como requisito parcial para a obtenção do Título de Bacharel em Direito.

Orientador(a): Bruno Vaz de Carvalho 


\section{Dedicatória}

À minha mãe, Marcia, minha maior incentivadora e a razão pela qual herdei o gosto pelo Direito.

Ao meu pai, Marcio, meu eterno mestre, que sempre será meu paradigma de conduta ética nas relações profissionais. 


\section{Agradecimentos}

Agradeço aos meus pais e ao Patrick que colaboraram imensamente para que eu atingisse os meus objetivos.

Agradeço ao professor e orientador Bruno Vaz de Carvalho, pelo apoio e encorajamento na realização do presente trabalho, aos demais Mestres desta Universidade, pelos conhecimentos transmitidos, e à Diretoria do curso de Direito, da PUC-RJ, pelo apoio institucional e pela dedicação.

Agradeço aos meus amigos de toda vida pelo eterno apoio e carinho.

Agradeço aos amigos do Villemor Amaral, dentre eles Gustavo e Erika, meus grandes professores da prática do Direito. 


\section{Resumo}

Os títulos de crédito representam um importante instrumento para a economia. Com o advento do Código Civil de 2002, ficou instituída a possibilidade de criação dos Títulos de Crédito Eletrônicos, o que gerou, e gera até os dias atuais, uma grande discussão acerca de um dos princípios basilares do Direito Cambiário: o da cartularidade. Assim, o meio informatizado vem, paulatina e decisivamente, substituindo o papel como meio físico de suporte aos títulos de crédito. É o fenômeno que a doutrina tem chamado de desmaterialização dos títulos de crédito, e que tem gerado um grande questionamento acerca da suposta fragilidade da segurança e do possível desrespeito aos princípios que regulam esses instrumentos. Este trabalho tem o objetivo de analisar as conseqüências jurídicas desse fenômeno e discutir a necessidade de uma alteração legislativa para abrigar juridicamente os títulos de crédito desmaterializados. Por fim, será demonstrado como o fenômeno da desmaterialização incide, com bastante intensidade, em relação à duplicata, que é um título de crédito genuinamente brasileiro, com larga utilização no comércio nacional.

Palavras chaves: Títulos de Crédito. Comércio eletrônico. Princípios cambiários eletrônicos. Duplicata virtual. 


\section{Sumário}

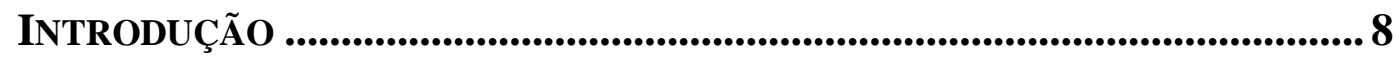

I. ConsideraÇões Gerais ACERCA DOS Títulos de CRÉDITO.............. 11

I.1. O crédito e a sua importância econômica ....................................... 11

I.2 Títulos de Crédito .............................................................................. 12

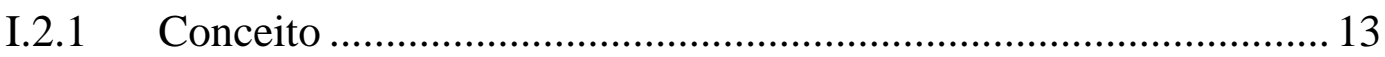

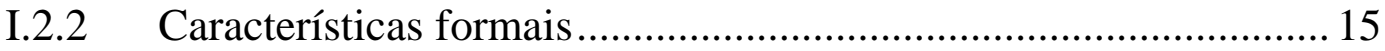

I.2.3 Princípios Cambiários ................................................................ 15

II. O COMÉRCIO ELETRÔNICO ...................................................................22

II.1 Os documentos eletrônicos e a sua validade jurídica ................. 25

II.2 A assinatura digital .................................................................................... 30

III. O TÍTULO DE CRÉDITO ELETRÔNICO..............................................34

III.1. A desmaterialização dos títulos de crédito .....................................35

III.2 Definição de título de crédito eletrônico .........................................39

III.3. Os princípios eletrônicos e o título de crédito eletrônico .......... 41

III.4. Lacuna no ordenamento brasileiro .................................................. 46

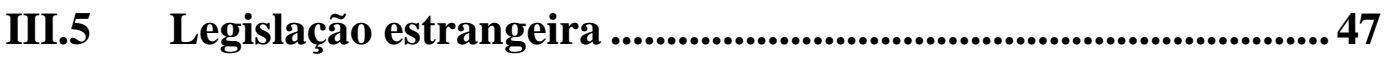

IV. A Duplicata Cartular e a Duplicata VirTual...........................51

IV.1. Aspectos da duplicata ..........................................................................552

IV.2. O modelo tradicional .......................................................................55

IV.3. A duplicata virtual .............................................................................. 58

IV.3.1 Caracterízação da duplicata virtual................................................ 63

IV.4. Vantagens e desvantagens da duplicata virtual ........................... 64

IV.5. A visão da doutrina na execução das duplicatas virtuais......... 65

V - CONCLUSÃO ................................................................................................... 71

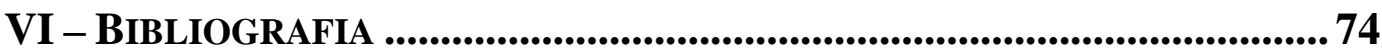




\section{Lista de Siglas e Abreviações}

Art. - Artigo

CC - Código Civil de 2002

CF - Constituição Federal da República Federativa do Brasil

CPC - Código de Processo Civil

EDI - Troca eletrônica de dados

ICP-Brasil - Infra-Estrutura de Chaves Públicas Brasileira

LD - Lei das Duplicatas (Lei no. 5.474/68)

MP - Medida Provisória

Uncitral - Comissão das Nações Unidas para o Direito Comercial Internacional

STJ - Superior Tribunal de Justiça 


\section{Introdução}

Os títulos de crédito consolidaram-se, ao longo da história, como um importante instrumento para a facilitação da circulação das riquezas e, consequentemente, para o fomento do desenvolvimento econômico. Entretanto, o extraordinário progresso no tratamento magnético das informações, experimentado nas últimas décadas, e a presença, cada vez maior, dos recursos de informática nas atividades comerciais e bancárias, trouxeram grandes consequiências para o instituto jurídico dos títulos de crédito.

O meio informatizado vem, paulatina e decisivamente, substituindo o papel como meio físico de suporte aos títulos de crédito. É o fenômeno que a doutrina tem chamado de desmaterialização dos títulos de crédito ou de títulos de crédito virtuais. Este fenômeno traz, de imediato, uma fragilização do princípio da cartularidade, a ponto de alguns Autores afirmarem que os títulos de crédito experimentam um período de decadência que poderá levar até mesmo à sua extinção. Por outro lado, uma adequada interpretação das normas jurídicas e, se necessário, a modernização destas, pode dar o suporte jurídico necessário ao rápido incremento das transações com títulos de crédito virtuais.

Será demonstrado que uma das grandes inovações do Código Civil de 2002, em relação aos Títulos de Crédito, foi o disposto no $\S 3^{\circ}$ do art. 889 , que reconhece a possibilidade de criação de um título de crédito a partir de um meio eletrônico.

Essa nova perspectiva - eletrônica, informatizada - a que se encontra submetida a atividade comercial e, nela, os títulos de crédito, ocasionou uma série de questionamentos, surgindo a indagação quanto a natureza jurídica daqueles documentos de crédito originados e formados no ambiente 
eletrônico e que, por isso, apresentam-se desmaterializados da cártula, ou seja, do documento de papel: seriam eles títulos de crédito?

Em caso positivo, seria possível a qualificação de título de crédito àqueles documentos formados no ambiente eletrônico apenas com uma nova interpretação das normas legais existentes, adequando-as a essa nova realidade ou, em contrário, uma reforma legislativa faz-se necessária para a qualificação pretendida?

É nessa perspectiva, buscando essas respostas que o presente trabalho será abordado, sem esquecer os conceitos tradicionais, ainda muito vivos no direito, porém problematizando-os em face de uma prática mercantil influenciada pela informática e que demanda uma nova compreensão dos títulos de crédito.

Como objetivos específicos, procurar-se-á: a) contextualizar o fenômeno da desmaterialização no desenvolvimento histórico dos títulos de crédito; b) analisar as conseqüências jurídicas do fenômeno da desmaterialização dos títulos de crédito; c) apontar possíveis caminhos para o acolhimento jurídico dos títulos de crédito desmaterializados e, d) apresentar os diversos entendimentos doutrinários e jurisprudenciais acerca das duplicatas virtuais.

No primeiro capítulo, serão apresentadas as noções gerais de direito cambiário. Inicia-se com uma breve revisão do desenvolvimento histórico dos títulos de crédito. Segue-se com o estudo do conceito de título de crédito, dos princípios de direito cambiário e das modalidades previstas pela legislação pátria. Um dos objetivos do capítulo inicial é criar bases para uma contextualização histórica do fenômeno da desmaterialização dos títulos de crédito e disponibilizar conceitos básicos do direito cambiário. 
No segundo capítulo discutiremos os aspectos do Comércio Eletrônico, onde serão analisadas as circunstâncias de sua criação, bem como as suas características e os projetos de Lei em tramitação, que visam a sua regulamentação. Enfatizaremos a atribuição da validade jurídica aos documentos eletrônicos e a assinatura digital.

No terceiro capítulo, trataremos do fenômeno da desmaterialização dos títulos de crédito. Procura-se demonstrar os fatores impulsionadores do fenômeno da desmaterialização, abordando-se a substituição do papel por meios informatizados, em razão do comércio eletrônico e do desenvolvimento do sistema bancário no Brasil. Por fim, será realizada uma análise das conseqüências jurídicas desse fenômeno, estudando a fragilização dos princípios de direito cambiário e discutindo a necessidade de alteração legislativa para abrigar juridicamente os títulos de crédito desmaterializados.

No quarto e último capítulo, serão apresentados os modelos, tradicional e virtual, de compra e venda com saque de duplicatas, que têm sido praticados pelo comércio, possibilitando a caracterização da duplicata virtual e discutindo, por fim, a executividade das mesmas.

Finalmente, concluindo o presente estudo, algumas considerações são traçadas sobre os títulos de crédito virtuais, sua importância no cenário atual e as necessidades de adequação do meio jurídico a esses novos mecanismos de crédito. 


\section{Considerações Gerais acerca dos Títulos de Crédito}

\section{I.1. O crédito e a sua importância econômica}

É imprescindível, inicialmente, entender o conceito de crédito e a sua importância na economia moderna.

A palavra crédito, que tem sua origem etimológica derivada do latim creditum, tem seu fundamento na idéia de confiança. Segundo a doutrina, o crédito materializa-se através da venda a prazo e do empréstimo, oportunizando, primeiramente, o consumo e, posteriormente, a respectiva reposição. Ou seja, significa a confiança que uma pessoa deposita em outra, a quem entrega coisa sua, para que, no futuro, receba algo em troca.

$\mathrm{O}$ crédito possui dois elementos fundamentais: a confiança e o tempo. A confiança baseia-se na certeza que o credor tem na pessoa que vai se tornar sua devedora, em virtude da entrega da coisa, que esta possui capacidade econômica para lhe restituir a futura prestação que será devida. O tempo corresponde ao período que intercala a prestação presente, ou seja, a entrega da coisa, e a prestação futura, que é a restituição do valor pelo devedor.

Como bem ensina FRAN MARTINS ${ }^{1}$ :

"O crédito, ou seja, a confiança que uma pessoa inspira a outra de cumprir, no futuro, obrigação atualmente assumida, veio facilitar grandemente as operações comerciais, marcando um passo avantajado para o desenvolvimento das mesmas".

\footnotetext{
${ }^{1}$ MARTINS, Fran. Títulos de crédito. $13^{\mathrm{a}}$ ed. Rio de Janeiro: Forense, 2002. vol. 1. p. 3.
} 
Desde sua origem até as atuais e sofisticadas operações mercantis, o crédito sempre teve como principal objetivo tornar mais rápidas e eficientes as transações comerciais entre as pessoas.

Contudo, a utilização do crédito passou a evidenciar um problema em relação à circulação dos direitos creditórios. Ressalta-se que, no passado, a obrigação pecuniária só poderia ser cumprida pela própria pessoa que a contraiu. Assim, se uma pessoa contraísse uma dívida, o seu patrimônio não poderia responder pela mesma, já que o entendimento à época era da existência da união entre pessoa e patrimônio, sendo o patrimônio tido com um assessório da pessoa.

Esse entendimento só foi modificado com o surgimento da Lex Poetelia Papira ${ }^{2}$, que fez a distinção entre patrimônio e pessoa, possibilitando a execução do patrimônio do devedor para extinguir a obrigação.

Surgiu, então, a necessidade de criar instrumentos que possibilitariam a rápida circulação de riquezas e direitos creditórios.

Assim, na Idade Média, surgiram os títulos de crédito, documentos hábeis para mobilizar riquezas, através da sua alta negociabilidade, resolvendo, também, o problema da circulação de direitos creditórios ${ }^{3}$.

\section{I.2 Títulos de Crédito}

Com o surgimento dos títulos de crédito, a sociedade ganhou um instrumento imprescindível para o seu progresso, pois é manifesta a sua

\footnotetext{
${ }^{2}$ Existe uma divergência doutrinária em relação ao período no qual surgiu a Lex Poetelia Papiria. ${ }^{3}$ ROSA JUNIOR, Luiz Emygdio Franco da. Títulos de Crédito. $5^{\mathrm{a}}$ ed. Rio de Janeiro: Renovar, 2007. p. 39
} 
importância em diversas áreas, dentre elas a econômica, civil e comercial. E esta importância influenciou a sua própria legislação cambiária.

\section{I.2.1 Conceito}

A definição de título de crédito não gera grandes discussões entre os juristas, sendo certo que a maioria adota o notável conceito formulado por CESARE VITANTE", que define o título de crédito como "o documento necessário para o exercício do direito, literal e autônomo, nele mencionado".

Através da definição do mestre italiano, podemos deduzir que, inexistindo um documento, ou seja, um escrito em algo material, palpável e corpóreo, inexiste o título de crédito. Assim, para exercer os direitos mencionados no título, o possuidor deve apresentá-lo ao devedor, razão pela qual o documento é necessário para o exercício dos direitos nele mencionados.

Ainda pela definição de CESARE VIVANTE, o direito incorporado no título (sempre direitos de crédito ${ }^{5}$ ) é literal, entendendo-se que só vale o que está escrito. Já a autonomia dos direitos, diz respeito à independência das obrigações, no sentido de que a obrigação assumida por uma pessoa não tem vínculo com as obrigações assumidas anteriormente, por outras pessoas, no mesmo título.

Dessa forma, ratificando o conceito de CESARE VIVANTE, o Código Civil Brasileiro de 2002, ao definir título de crédito, em seu artigo 887, assim se pronunciou:

\footnotetext{
${ }^{4}$ Apud COELHO, Fábio Ulhoa. Curso de Direito Comercial. 5a ed. São Paulo: Saraiva, 2001. v. 01. p. 363.

${ }^{5}$ MARTINS, Fran. Op. cit., p. 06.
} 
"Art. 887. O título de crédito, documento necessário ao exercício do direito literal e autônomo nele contido, somente produz efeito quando preencha os requisitos da lei."

A partir desse conceito, fica claro que o título de crédito, ao permitir o exercício do direito literal e autônomo nele contido, incorpora uma obrigação.

É importante frisar que os títulos de crédito possuem alguns atributos que são essenciais para a sua maior agilidade e garantia da obrigação. Podemos destacar duas importantes características: (i) a circulabilidade e (ii) a executividade.

A circulabilidade representa a facilidade de circulação do crédito incorporado no título. Desse modo, um título de crédito pode ser transferido pelo portador para outra pessoa (o meio mais comum de transferência é o endosso ${ }^{6}$ ).

A executividade representa a garantia de cobrança do credor, através do Judiciário, para satisfazer o crédito. Ressalta-se que, a legislação processual $^{7}$ confere ao título de crédito, natureza executiva extrajudicial, que independe de prévia constituição judicial do título.

Dessa forma, o credor de um título de crédito - tendo em vista a natureza de título executivo extrajudicial que a legislação lhe confere e a da facilidade de circulação - possui uma maior segurança para ter garantida a obrigação.

\footnotetext{
${ }^{6}$ Endosso é a forma jurídica pela qual transfere-se o documento e os direitos cambiários nele incorporado, mediante a assinatura de seu portador.

${ }^{7}$ Art. 585 do Código de Processo Civil: São títulos executivos extrajudiciais:
} 


\subsubsection{Características formais}

O elemento preponderante para a existência do título de crédito é o formalismo e sem ele não terão eficácia os demais princípios próprios do direito cambiário. A formalização dos títulos de crédito ocorre pela via documental.

Nos dizeres de FRAN MARTINS ${ }^{8}$ :

"O formalismo dá a natureza do título, transformando o escrito de um simples documento de crédito em um título que se abstrai de sua causa, que vale por sim mesmo, é per se stante."

Assim, cada espécie de título - letra de câmbio, nota promissória, duplicata, etc - deverá conter os requisitos expressos na lei, para ter validade jurídica. As características formais de cada título se encontram disciplinadas pela legislação referente à cada uma das espécies.

Esse apego ao formalismo está diretamente ligado à segurança e à confiança que se quer transmitir quando ocorre a circulação do título de crédito.

É por isso que os documentos que não cumprirem a forma exigida pela lei, não terão o valor de título de crédito.

\subsubsection{Princípios Cambiários}

Os princípios cambiários permitiram que os títulos de crédito evoluíssem, cumprindo a sua finalidade de ser negociável e protegendo, principalmente, o terceiro adquirente de boa fé. 
Três são os princípios adotados pela maioria dos juristas. Esses princípios correspondem a verdadeiros atributos do título de crédito, servindo para diferenciá-lo dos outros documentos e sendo responsáveis pela dinâmica e celeridade do crédito. São eles: a literalidade, a autonomia e a cartularidade.

\section{Literalidade}

A literalidade consiste no fato de que somente o que está expresso no título é o que vale, sendo assim, é imprescindível que o direito decorrente do título esteja explícito no documento.

Como bem elucida FRAN MARTINS, "o princípio da literalidade vai mais além: significa que tudo o que está escrito no título tem valor e, consequentemente, o que nele não está escrito não pode ser alegado"".

Assim, qualquer outro documento separado do título, mesmo que contenha alguma declaração em relação ao direto cambiário, não possui nenhum valor.

LUIZ EMYGIO DA ROSA JR. ${ }^{10}$ é claro e objetivo ao definir o princípio da literalidade:

\footnotetext{
"O princípio da literalidade, explica-se pelo rigor formal que caracteriza o título de crédito, objetivando a proteção do terceiro de boa-fé porque a forma do título determina a natureza e a extensão da obrigação cambiária do subscritor.

(...)

Ademais, não tem qualquer valor cambiário declaração constante de documento em separado do título, como, por exemplo, uma carta dirigida pelo seu beneficiário ao terceiro adquirente, dando ciência que lhe está endossando o título"
}

\footnotetext{
${ }^{9}$ MARTINS, Fran. Op. cit., p.17.

10 ROSA JUNIOR, Luiz Emygdio Franco da. Títulos de Crédito. $5^{\mathrm{a}}$ ed. Rio de Janeiro: Renovar, 2007. p. 62.
} 
A literalidade pode ser explicada através do formalismo do título de crédito, que tem como objetivo a proteção do terceiro de boa-fé, pois o que está escrito no título é exatamente a obrigação cambiária assumida pelos que figuram no documento.

Porém, é importante lembrar que literalidade não se confunde com formalismo, pois ambos têm estrutura e funções diversas. Como já visto, o formalismo é estabelecido pela lei e define o teor específico do documento, sem o qual estará comprometida a sua existência. A literalidade visa unicamente ao teor do que está escrito, atribuindo relevância jurídica aos elementos contidos no documento.

Assim, sendo o título de crédito um documento necessário para o exercício de um direito, é necessário que nele estejam expressos os seus limites e a sua amplitude, a fim de que possibilitem ao credor a indispensável segurança, liquidez e certeza jurídica.

\section{Autonomia}

O segundo princípio, e um dos mais importantes, é o da autonomia, pois ele é capaz de promover com segurança a circulação dos direitos resultantes dos títulos de crédito. Assim, aquele que adquire um título de crédito proveniente de um negócio, onde ele não fazia parte, não pode ser prejudicado por desarranjos futuros, que deverão ser satisfeitos de forma diversa que não a suspensão da satisfação da obrigação.

PONTES DE MIRANDA ${ }^{11}$, em mais uma de suas brilhantes alegações, refere-se da seguinte forma acerca do princípio da autonomia:

"A necessidade de assegurar a circulação cambiária levou à concepção da autonomia das obrigações cambiárias. Certamente, o título cambiário é unidade, e

\footnotetext{
${ }^{11}$ MIRANDA, Pontes de. Tratado de Direito Cambiário. 2aed. São Paulo: Max Limonad, 1954. vol. 01. p.119.
} 
por vezes o designamos pela expressão ato unitário; mas, coexistente com a aparência do todo, há a aparência dos outros singulares, cujo despregamento resulta do fato mesmo das assinaturas, que são diversas e lançadas em diversos tempos. Seria sem história e, portanto, sem traços do tráfico, título em que, a despeito da multiplicidade das mãos por que andou, recebesse declarações bilaterais de vontade, sem lhes assegurar autonomia. O andar deu-lhe o ser solto soltura que se reflete como vimos na solidariedade cambiária."

O princípio da autonomia manifesta a independência das relações cambiárias, ou seja, o direito do proprietário de um título de crédito, desde que tenha circulado, não tem qualquer vínculo com a relação antecessora.

Cabe aqui transcrever uma pequena passagem de BULGARELLI ${ }^{12}$, que define claramente o princípio da autonomia:

"A autonomia é requisito fundamental para a circulação dos títulos de crédito. Por ela, o seu adquirente passa a ser titular de direito autônomo, independente da relação anterior entre os possuidores. Em consequência, não podem ser oponíveis ao cessionário de boa fé as exceções decorrentes da relação extracartular, que eventualmente possam ser opostas ao credor originário."

Assim, todos que subscrevem um título de crédito assumem obrigações independentes, distintas das contraídas por outros que, no mesmo título, opuseram as suas assinaturas.

A consequência jurídica da autonomia em relação à inoponibilidade das exceções pessoais aos terceiros de boa-fé delimita, processualmente, as matérias passíveis de serem opostas pelo um devedor de um título de crédito executado. Ou seja, não é lícito ao devedor opor exceções de natureza pessoal àquela contra quem não estabeleceu relação direta.

Em relação à inoponibilidade das exceções, é dessa forma que elucida FRAN MARTINS ${ }^{13}$ :

${ }^{12}$ BULGaRELLI, Waldiro. Títulos de Crédito: Direito Comercial III. 1 ${ }^{a}$. ed. São Paulo: Atlas S.A., 1979. p. 55.

${ }^{13}$ MARTINS, Fran. Op. cit., p.12-13. 


\begin{abstract}
"Decorrência do princípio da autonomia da obrigação cambiária (cada obrigação é autônoma e independente, não ficando a sua validade subordinada a uma outra obrigação - donde se concluir que cada obrigado se obriga não apenas com a pessoa a quem transfere o título mas com o portador do mesmo, seja ele quem for), surgiu a regra chamada da inoponibilidade das exceções. Por essa regra consagrada no art. 17 da Lei Uniforme, o obrigado em uma letra não pode recusar o pagamento ao portador alegando as suas relações pessoais com o sacador ou outros obrigados anteriores do título (como por exemplo, não pode o obrigado recusar o pagamento alegando que é o credor do sacador). Tais exceções ou defesas são inoponíveis ao portador, que fica, sempre, assegurado quando ao cumprimento da obrigação pelo obrigado."
\end{abstract}

Dessa forma, a autonomia de um título está no fato de que o possuidor pode exercê-la como se fosse decorrência de um direito originário, em razão da inoponibilidade de exceções que garante.

Pode-se, então, concluir que a expressão autonomia, para a maior parte da doutrina, indica que o direito do titular é um direito independente no sentido de que cada pessoa, ao adquirir a cártula, recebe um direito próprio, diferente do direito que tinha ou podia ter quem lhe transferiu o mencionado título.

\title{
Cartularidade
}

Segundo FÁBIO ULHOA “o princípio da cartularidade é a garantia de que o sujeito que postula a satisfação do direito é mesmo o seu titular (...). A cartularidade é, desse modo, o postulado que evita o enriquecimento indevido de quem, tendo sido credor de um título de crédito, o negociou com terceiros" ${ }^{14}$.

Esse princípio é a conseqüência direta dos dois princípios citados anteriormente. Isso porque, para que um determinado credor possa exercer os direitos representados por um título de crédito, é necessária a existência de um documento, o qual foi atribuído a denominação de cártula.

\footnotetext{
${ }^{14}$ COELHO, Fábio Ulhoa. Op. cit., p. 366.
} 
Portanto, cártula significa o direito abstrato que se incorpora e que passa a se apresentar sob a forma de título. É a exteriorização do título por meio de um documento, sendo a exibição desse documento necessária para o exercício do direito de crédito nele mencionado.

\section{Nos dizeres de BULGARELLI ${ }^{15}$ :}

"A cartularidade, também chamada de incorporação, notadamente pelos autores espanhóis modernos, como Broseta Pont e Rodrigo Uria, e pelo nosso Eunápio Borges, e que consiste, em última análise, na materialização do direito, no documento. Daí se dizer que o direito se incorpora ao documento, expressão empregada até mesmo por Cesare Vivante. A expressão cartularidade ou direito cartular (de chartula, do baixo latim) é empregada para significar tanto a incorporação do direito ao documento, como o direito decorrente do título em relação ao negócio fundamental, chamado por isso mesmo negócio subjacente, de relação extracartular (na Espanha, extracartacea).

Assim, deve-se ter presente que um negócio qualquer, quando gera a emissão de um título de crédito, passa a ser, perante o título, negócio ou relação extracartular, enquanto o título se apresenta como cártula.

Pelo direito cartular, o documento torna-se essencial à existência de direito nele mencionado, e necessário para a sua exigência, tornando-se legítima a cobrança pelo titular que o adquiriu regularmente (função de legitimação). Portanto, em decorrência da incorporação do direito no título:

a) quem detenha o título, legitamente, pode exigir a prestação;

b) sem o documento, o devedor não está obrigado, em princípio, a cumprir a obrigação."

Dessa forma, verifica-se que a cartularidade decorre do atributo da autonomia do título de crédito. E é em razão do direito mencionado nesse título literal e autônomo, que a apresentação da cártula se faz necessária para o exercício do direito.

Daí porque, sem a apresentação do título de crédito, não está o devedor obrigado a cumprir a obrigação. Assim, é indispensável para a exigibilidade do crédito, a exibição do documento original.

\footnotetext{
${ }^{15}$ BULGARELLI, Waldiro. Op. cit., p. 53-54.
} 
Esta é a razão pela qual CESARE VIVANTE, a maior parte da doutrina e o Código Civil Brasileiro, adotaram a expressão "documento necessário ao exercício do direito literal e autônomo nele contido".

Dessa forma, ao adotar essa expressão, o legislador demonstra claramente que, a fim de exercer o direito cambiário, é necessária a apresentação do título onde constam as obrigações e direitos nele incorporados.

Ao longo desse trabalho, porém, veremos que o Código Civil de 2002 trouxe, em sua nova redação, uma pequena mudança, que passou a questionar a necessidade da real existência de um documento cartular necessário para exigir o cumprimento da obrigação. 


\section{II. $O$ comércio eletrônico}

No capítulo anterior, foram analisados, resumidamente, alguns aspectos que levaram a criação dos títulos de crédito. Foi, também, demonstrada a importância do crédito na história econômica da sociedade e, como o seu surgimento teve como principal objetivo a rápida circulação de riquezas e direitos creditórios.

Nesse capítulo, será abordado o direito cambiário dentro de uma nova fase, que é marcada pela influência dos modernos e sofisticado meios de informática nas relações de comércio, inclusive nos negócios realizados através dos títulos de crédito.

Primeiramente, cabe definir o que é a Internet. REGIS MAGALHÃES SOARES DE QUEIROZ a define como:

\footnotetext{
"Um metaterritório - transcendente em relação ao território físico porque criado virtualmente por meio de maciça interligação de redes de computadores espalhados pelo mundo que, portanto, não conhecem fronteiras físicas -, onde é possível armazenar e divulgar todo tipo de informação, pela transferência de arquivos de computador para computador, utilizando os meios e a infra-estrutura de comunicação disponíveis, permitindo o estabelecimento de toda sorte de relações jurídicas e sociais."
}

Com a ampla disseminação da Internet na vida das pessoas, abrangendo, dentre outras, as áreas de lazer, arte e cultura, tornou-se inevitável que fosse ela utilizada com uma finalidade que viesse a gerar lucros: o comércio.

Passou-se, então, a serem comerciados, em lojas virtuais, tanto bens imateriais (compra de software, informação sobre serviços, reserva em hotéis etc.) quanto bens móveis. Como as partes não se faziam presentes 
fisicamente e nem se conheciam, essa modalidade de comércio difundiu-se rapidamente. Em parte, por causa da comodidade em se adquirir bens não acessíveis na própria cidade do adquirente. Isso, apesar do inconveniente para o consumidor, na quase totalidade das vezes, da exigência de que este cumprisse primeiramente a sua obrigação de efetuar o pagamento através de cheque, boleto bancário ou cartão de crédito.

Satisfeita a obrigação, só então o vendedor dava início à sua obrigação contratual, remetendo ao adquirente, via download, o produto informático ou, no caso de mercadoria física, através do correio, geralmente acrescida da despesa postal. Esses negócios passaram a ser realizados de uma forma nova mediante acordos exclusivamente via Internet, ou seja, em um ambiente em que os contratantes não se conhecem, não se vêem, nem podem se assegurar de que a outra parte seja realmente quem diz ser e que adimplirá o convencionado. Dessa forma, inequivocadamente, estão inseridos nessa modalidade contratual, a confiança e o risco.

Foi assim, com a prática do comércio via Internet, que foi construído o esqueleto dessa nova forma de contratar. Tratando-se de uma nova modalidade de contrato, o assim chamado comércio eletrônico expandiu-se, na fase inicial, por impulso próprio, com riscos calculados, sem o concomitante aval legislativo, uma vez que quase sempre a reforma legal está descompassada da realidade temporal.

Nesse sentido, elucida WALD "houve, de início, a assunção, pelos meios comerciais, de um risco calculado para fazer funcionar o sistema, elaborando-se, em seguida, as normas cabíveis"17.

\footnotetext{
${ }^{16}$ QUEIROZ, Regis Magalhães Soares de; FRANÇA, Henrique de Azevedo Ferreira. A assinatura digital e o tabelião virtual. In: LUCCA, Newton de; SIMÃO FILHO, Adalberto (Org.). Direito \& Internet. $1^{\text {a }}$ reimp.. São Paulo: EDIPRO, 2001. p. 373.

${ }^{17}$ WALD, Arnoldo. Um novo direito para uma nova economia. In GRECO, Marco Aurélio; MARTINS, Ives Gandra da Silva (Org.). Direito e Internet: relações jurídicas na sociedade informatizada. São Paulo: RT, 2001. p. 19.
} 
Ressalta-se que, esse avanço da informática nos documentos representativos de crédito não vem sendo acompanhado pela disciplina jurídica, indispensável à segurança que as relações comerciais demandam. Parece que, as pessoas, de um modo geral, e a comunidade jurídica, em particular, não se sentem seguras acerca da conveniência da substituição do papel pelo documento eletrônico.

Destaca-se que, não estamos discutindo sobre a substituição absoluta do papel como documento, pois tal situação seria praticamente impossível, mas sim disciplinar as transações comerciais realizadas através do meio magnético.

Mesmo porque, aquilo que é chamado de virtual na linguagem da informática, como bem diz o filósofo francês PIERRE LEVY "não se opõe ao real, mas ao atual: virtualidade e atualidade são apenas duas maneiras de ser diferentes" ${ }^{\prime 18}$.

Desse modo, ao abordar a prática comercial informatizada, leva-se em conta que, a maioria dos empresários, nos dias de hoje, ao realizar negócios, não utilizam somente do tradicional papel (cártula) como documento de escrituração, mas, também, do meio eletrônico.

Diante dessa nova realidade, como fica, por exemplo, o princípio da cartularidade - que pressupõe a existência física de um documento - no direito cambiário? Esse é o principal ponto do presente trabalho, que será detalhado ao longo dos próximos capítulos. Por ora, iremos analisar três importantes questões acerca do comércio eletrônico: o documento eletrônico, a sua validade jurídica e a assinatura digital.

\footnotetext{
${ }^{18}$ LEVY, Pierre. O que é virtual? Disponível em < http://books.google.com.br. $>$ Acesso em 03 maio 2009.
} 


\section{II.1 Os documentos eletrônicos e a sua validade jurídica}

Segundo PONTES DE MIRANDA, documento é "toda coisa que expressa, por meio de sinais, o pensamento" ${ }^{19}$. É necessário ressaltar que, nesse entendimento adotado pela maioria dos juristas, não se vislumbra nenhuma referência à obrigatoriedade de um papel para que a manifestação seja considerada como um documento.

Com a Internet sendo cada vez mais utilizada, em razão da sua rápida expansão na sociedade, surgiu, então, um novo tipo de documento: o eletrônico, que pode ser definido, resumidamente, como "aquele que foi gerado ou arquivado por sistema computadorizado, em meio digital." 20

Como já mencionado anteriormente, e muito bem explicado por SILVÂNIO COVAS, "a informática oferece um desdobramento de dimensão além do plano físico que se conhece, criando, verdadeiramente, um novo ambiente para a atuação humana - o ciberespaço" ${ }^{21}$.

Assim, a informática ocasionou uma revolução que ultrapassa as fronteiras do campo meramente técnico, fazendo nascer os bens virtuais e a separação entre o meio físico e as mensagens que a ele podem ser agregadas.

Dessa forma, como bem elucida AUGUSTO TAVARES ROSA MARCACINI, "para o Direito, entretanto, o documento eletrônico ainda é fonte de alguma perplexidade: essencialmente alterável, por natureza,

\footnotetext{
${ }^{19}$ MIRANDA, Pontes de. Comentários ao Código Civil. $3^{\mathrm{a}}$ ed. Rio de Janeiro: Forense, 1996. Tomo IV. p. 338.

${ }^{20}$ QUEIROZ, Regis Magalhães Soares de; FRANÇA, Henrique de Azevedo Ferreira. A assinatura digital e o tabelião digital. In: LUCCA, Newton de; SIMÃO FILHO, Adalberto (Org.). Direito \& Internet. São Paulo: EDIPRO, 2000. p. 380.

${ }^{21}$ COVAS, Silvânio. O contrato no ambiente virtual. Contratação por meio da informática. Revista de Direito Bancário e de Mercado de Capitais. São Paulo: Revista dos Tribunais, ano 02, n. 05, p. 102, maio/agosto, 1999.
} 
poderia ser comparado ao documento tradicional, lançado em meio corpóreo, como o papel?",22

Resumidamente, a explicação técnica é a de que, assim como o documento tradicional se compõe de escrito com pigmento de tinta sobre objeto corpóreo denominado papel, o documento digital nada mais é do que uma representação por códigos binários, guardados magneticamente em suporte até então não convencional ( $\mathrm{cd}$, o pen drive ou o disco rígido de um computador). É importante frisar que o documento continua disponível, acessível e inteligível, sendo somente uma simples substituição de um suporte clássico por um magnético.

Ou seja, o documento eletrônico não se prende ao meio físico em que está gravado, possuindo autonomia em relação a ele. Vale lembrar que, o documento cartular não se resume a palavras, podendo ser um documento escrito, mas também desenhos, fotografias, desenhos, vídeos, enfim, tudo o que puder representar um fato. $\mathrm{O}$ mesmo se aplica a um documento que esteja armazenado em um arquivo digital.

Conforme defende a maioria dos juristas, o documento eletrônico possui como pontos críticos (i) a comprovação da identidade das partes, tanto na autoria quanto na aceitação e (ii) a prova do seu conteúdo e da sua integridade. Destaca-se que, atualmente, o fenômeno da desmaterialização dos documentos tem causado grandes discussões.

Ademais, uma das principais preocupações das partes envolvidas, em qualquer negócio, é a validade que este documento possui. Por isso, os aspectos formais do documento são fundamentais para que seja mantida a segurança jurídica da relação.

\footnotetext{
${ }^{22}$ MARCANCINI, Augusto Tavares Rosa. O documento eletrônico como meio de prova. Revista da Associação Brasileira de Propriedade Industrial (ABPI), São Paulo, n.058, p.03, maio/junho, 2002.
} 
AUGUSTO TAVARES ROSA MARCACINI ${ }^{23}$ é muito claro ao analisar alguns pontos problemáticos que envolvem dos documentos eletrônicos:

"O documento físico consiste em um meio tangível, onde a informação está escrita, normalmente, em um papel. É comum que instrumentos sejam feitos em um maior número de vias, distribuídas entre os signatários. Esses conceitos, de documento original, ou de vias de um mesmo documento, são existentes no meio eletrônico. O documento eletrônico é uma sequência de bits e, onde quer que esteja gravado, em qualquer quantidade de cópias, mas desde que seja reproduzida exatamente a mesma sequência, teremos sempre o mesmo documento. Dado o fato que o documento eletrônico pode ser copiado infinitas vezes, mantendo-se exatamente igual à matriz, é impossível falar-se em original, em cópia ou em número de vias do documento eletrônico. Toda "cópia" do documento eletrônico terá sempre as mesmas características do "original" e, por isso, deve assim ser considerada."

Esses pontos são importantes de serem analisados porque, como dito anteriormente, é necessário conferir autenticidade aos documentos eletrônicos, para, assim, garantir a sua validade. Surgiu, então, como meio para solucionar tal problema, a assinatura digital, capaz de conferir a autenticidade desse tipo de documento.

Cabe destacar que, um documento eletrônico, assinado digitalmente, conforme diretrizes da Medida Provisória 2.200/01, é considerado um documento original.

A MP 2.200/01 trouxe um enorme avanço, pois estabelece que os documentos e as declarações eletrônicas certificadas na forma descrita na mesma, se equiparam aos documentos físicos e passam a seguir as mesmas regras existentes para eles. Veja-se o art. 10 da mencionada Medida Provisória:

"Art.10. Consideram-se documentos públicos ou particulares, para todos os fins legais, os documentos eletrônicos de que trata esta Medida Provisória.

\footnotetext{
${ }^{23}$ MARCANCINI, Augusto Tavares Rosa. Op. cit., p.06.
} 
\$1 $1^{\mathbf{0}}$ As declarações constantes dos documentos em forma eletrônica produzidos com a utilização de processo de certificação disponibilizado pela ICP-Brasil presumem-se verdadeiros em relação aos signatários, na forma do art. 131 da Lei no 3.071, de 1o de janeiro de 1916 - Código Civil.

\$2 O disposto nesta Medida Provisória não obsta a utilização de outro meio de comprovação da autoria e integridade de documentos em forma eletrônica, inclusive os que utilizem certificados não emitidos pela ICP-Brasil, desde que admitido pelas partes como válido ou aceito pela pessoa a quem for oposto o documento."

Não faz sentido, portanto, a exigência ou a dispensa da apresentação, em objeto "papel", de um documento original só porque firmado eletronicamente.

Outro ponto que merece ser destacado é que o documento eletrônico também possibilita fazer prova irrefutável de sua autoria e integridade. Evidentemente, são necessários que estejam presentes alguns requisitos para a sua validade. Tal documento deve possuir recursos que lhe garantam a sua autenticidade e integridade. Tudo isso será possível com o uso da assinatura digital, como será visto mais adiante próximo subitem.

Por fim, uma questão que pode ser facilmente superada é em relação à aceitação dos documentos eletrônicos como meio de prova. Prova é a representação de um fato que, após análise cognitiva, é capaz de alterar a convicção do órgão julgador acerca dos fatos controversos ou não suficientemente esclarecidos.

Sabe-se que o Brasil tem um sistema probatório regido pelo princípio da livre apreciação das provas pelo Juiz e o da liberdade probatória. Esses princípios estão expressos no Código de Processo Civil, nos artigos 131 e 332, in verbis:

"Art. 131. O juiz apreciará livremente a prova, atendendo aos fatos e circunstâncias constantes dos autos, ainda que não alegados pelas partes; mas deverá indicar, na sentença, os motivos que Ihe formaram o convencimento. 
Art. 332. Todos os meios legais, bem como os moralmente legítimos, ainda que não especificados neste Código, são hábeis para provar a verdade dos fatos, em que se funda a ação ou a defesa."

Diante desses artigos, os documentos eletrônicos poderiam ser livremente utilizados nos negócios da vida cotidiana, tendo em vista que, caso houvesse algum questionamento e este fosse remetido ao Judiciário, um Juiz saberia apreciar o valor probatório de tais documentos.

Mesmo porque, o próprio Código Civil de 2002 admite, indiretamente, o uso de documentos eletrônicos como meio de prova, através do art. 212, II, combinado com o art. 225. Veja-se:

"Art. 212. Salvo o negócio a que se impõe forma especial, o fato jurídico pode ser provado mediante:

$$
\begin{aligned}
& \text { I - confissão; } \\
& \text { II - documento; } \\
& \text { III - testemunha; } \\
& \text { IV - presunção; } \\
& \text { V - perícia. }
\end{aligned}
$$

Art. 225. As reproduções fotográficas, cinematográficas, os registros fonográficos e, em geral, quaisquer outras reproduções mecânicas ou eletrônicas de fatos ou de coisas fazem prova plena destes, se a parte, contra quem forem exibidos, não lhes impugnar a exatidão." (grifos nossos)

Ora, se a lei não estabelece requisitos especiais de forma, isto é, havendo liberdade de forma e não exigência de solenidades especiais, as mensagens trocadas - mediante o uso de assinaturas digitais - entre pessoas capazes e legítimas, as vinculam, podendo, então, serem exibidas como prova em tribunais, já que tanto autoria quanto integridade das mensagens estarão comprovadas. Poder-se-ia, então, deduzir que, tecnicamente, um texto com assinatura eletrônica validada por autoridade certificadora pública (tabelião virtual) conteria capacitação para garantir: (i) a manutenção da integridade original de um documento digital (impossibilitando adulterações posteriores) e, (ii) a autoria dos contratantes 
(assegurando ao contratante eletrônico que a outra parte é realmente quem diz ser).

Quanto a isso, pode-se concluir que a Medida Provisória retrocitada, por si só, foi suficiente para validar a prova eletrônica.

Não obstante, cabe lembrar que existe o Projeto de Lei no 4.906/2001 que dispõe sobre o valor probante do documento eletrônico e da assinatura digital, regula a certificação digital e institui normas para as transações de comércio eletrônico.

O referido Projeto de Lei garante que não serão negados efeitos jurídicos, validade e eficácia ao documento eletrônico, pelo simples fato de apresentar-se em meio eletrônico. Assim, as declarações constantes de um documento eletrônico presumem-se verdadeiras em relação ao signatário, nos termos do Código Civil, desde que a assinatura digital seja única e exclusiva para o documento assinado, passível de verificação pública, gerada com chave privada cuja titularidade esteja certificada por autoridade certificadora credenciada e seja mantida sob o exclusivo controle do signatário.

Dessa forma, caso o referido Projeto de Lei seja aprovado, acabará com todos os obstáculos impostos pelos doutrinadores e juízes em relação à validade dos documentos eletrônicos, inclusive como meio de prova.

\section{II.2 A assinatura digital}

Como é cediço, um dos requisitos essenciais dos títulos de crédito é a assinatura, em razão da segurança que confere ao documento. Ocorre que, com os títulos de crédito virtuais, a assinatura "convencional" passa a ser impossível de ser utilizada. O que não significa que inexiste uma 
modalidade de assinatura capaz de preencher esse requisito. Essa modalidade diferenciada é chamada de assinatura digital.

Quando nos referimos a assinatura, a associação imediata que se faz é com o nome da pessoa firmado em um documento. Esta é a concepção mais comum da assinatura. No entanto, quando dizemos assinar algo, tanto podemos estar nos referindo à oposição do nome em um determinado documento, quando na oposição de um símbolo.

Mas qual seria a definição de assinatura digital?

MARLON MARCELO VOLPI define a assinatura digital como sendo "um mecanismo digital utilizado para fornecer confiabilidade, tanto sobre a autenticidade de um determinado documento eletrônico como sobre o remetente do mesmo" 24 .

Porém, a melhor definição de assinatura digital é dada pelo art. $2^{\circ}$, da Lei Modelo sobre Assinaturas Eletrônicas da Comissão das Nações Unidas para o Direito Comercial Internacional - Uncitral, versão de 2001:

\footnotetext{
"Por assinatura eletrônica se entenderão os dados em forma eletrônica consignados em ma mensagem de dados, ou incluídos ou logicamente associados ao mesmo, que possam ser utilizados para identificar que o signatário aprova a informação reconhecida na mensagem de dados." ${ }^{25}$
}

Ressalta-se que, a assinatura em um documento representa o meio de se identificar o seu autor, de garantir que o seu conteúdo é a vontade do mesmo e de garantir a sua legitimidade. Essas funções também devem ser

\footnotetext{
${ }^{24}$ VOLPI, Marlon Marcelo. Op. cit., p. 05.

${ }^{25}$ Texto original:

"For the purposes of this Law:

(a) "Electronic signature" means data in electronic form in, affixed to or logically associated with, a data message, which may be used to identify the signatory in relation to the data message and to indicate the signatory's approval of the information contained in the data message;" Disponível em < http://www.unicitral.org .> Acesso em 10maio.2009.
} 
aplicadas às assinaturas digitais. É o que nos ensina REGIS DE QUEIROZ $^{26}$ :

\begin{abstract}
"Para que um sistema de assinatura digital tenha a mesma força que a assinatura autográfica é preciso que, à sua maneira, ele também preencha os requisitos que garantam a identidade, a integridade e a peneridade do conteúdo: o uso e o controle da chave privada devem ser de exclusividade do proprietário, permitindo a individualização da autoria da assinatura (função declarativa); a autenticidade da chave privada deve ser passível de verificação, a fim de ligar o documento ao seu autor (autentificação, ligada à função declaratória); a assinatura deve estar relacionada ao documento de tal maneira que seja impossível a desvinculação ou a adulteração do conteúdo do documento, sem que tal operação seja perceptível, invalidando automaticamente a assinatura (função probatória)."
\end{abstract}

Dessa forma, com o uso da certificação eletrônica, tornou-se possível garantir a autenticidade e veracidade dos documentos eletrônicos. A técnica de certificação mais comum e segura é aquela realizada através dos processos de cifragem, que se dividem em dois: a criptografia simétrica ${ }^{27}$ (convencional) e a criptografia assimétrica ${ }^{28}$ (chave pública).

A criptografia é a ciência da transformação de dados, de maneira a torná-los incompreensíveis sem o conhecimento apropriado para sua tradução. Chave, na Internet, é o conjunto de dados usado em uma mensagem eletrônica para torná-la inalterável, bem como para, posteriormente, fazê-la retornar ao seu formato original.

Os atuais programas de criptografia são capazes de cifrar um documento eletrônico, seja ele texto (uma peça processual, um título de crédito eletrônico), som (uma audiência gravada, uma confissão) ou imagem (uma fotografia, um documento digitalizado) e marcá-lo com uma assinatura digital de tal forma que, se houver qualquer alteração no

\footnotetext{
${ }^{26}$ QUEIROZ, Regis Magalhães Soares de; FRANÇA, Henrique de Azevedo Ferreira. A assinatura digital e o tabelião virtual. In: LUCCA, Newton de; SIMÃO FILHO, Adalberto (Org.). Direito \& Internet. São Paulo: EDIPRO, 2000. p. 398.

${ }^{27}$ A criptografia simétrica é realizada através do uso de uma chave secreta que o emissor usa para codificar a informação e posteriormente o destinatário a utiliza para decifrá-la.
} 
documento, a chave pública não mais o abrirá, acusando a falsificação. Desse modo, foi obtida uma forma mais eficiente de garantir a autenticidade de um documento eletrônico.

O grande problema é quem irá garantir que determinada chave pertence à determinada pessoa. O controle das chaves tornou-se a questão crucial da força probatória dos documentos eletrônicos. Já existem várias empresas que realizam o trabalho de certificação das chaves públicas. Essas empresas são chamadas de certificadoras digitais, que funcionam como verdadeiros cartórios eletrônicos. O usuário registra sua chave pública na certificadora e toda vez que se fizer necessária à comprovação da autenticidade, basta que se envie eletronicamente a chave a ser autenticada e a empresa confirmará ou não o proprietário.

Este serviço já está regulamentado em vários países e está em vias de sê-lo no Brasil. O Projeto de Lei $\mathrm{n}^{\circ}$ 7.316, de 2002, visa normatizar a assinatura digital e as empresas certificadoras. A aprovação do referido Projeto de Lei é fundamental para pacificar o entendimento de que a assinatura digital é um meio seguro e eficiente.

Atualmente, as certificações eletrônicas são regulamentadas através da já mencionada MP no 2.200/01, que instituiu a Infra-Estrutura de Chaves Públicas Brasileira (ICP-Brasil).

\footnotetext{
${ }^{28}$ A criptografia assimétrica é baseada em um algoritmo de cifragem que utiliza duas chaves: uma pública e uma privada, onde a chave pública pode ser distribuída abertamente e a chave privada é mantida em segredo por seu gerador.
} 


\section{O Título de Crédito Eletrônico}

No capítulo anterior, foi realizada uma breve análise em relação à Internet, considerando a importância desse canal tecnológico no mundo comercial moderno, em que se inserem, também, os títulos de crédito eletrônicos.

Da mesma forma, foram feitas algumas considerações acerca do documento eletrônico, da sua validade jurídica e da sua eficácia probante, bem como sobre a assinatura digital, um processo eletrônico de certificação de mensagens, que tem como objetivo garantir a autenticidade e a veracidade dos documentos eletrônicos.

Tudo isso se deve às alterações significativas, que ocorreram nos últimos anos, face ao surgimento de modernas tecnologias, onde mecanismos se desenvolveram de modo a dispensar o uso de documentos sob a forma física.

Dessa forma, a chegada da informática acabou por afetar, de forma profunda, a disciplina dos títulos de crédito, dando vida eletrônica a tais instrumentos cambiários, sem, contudo, regulamentá-los.

Nesse capítulo, serão debatidos os títulos de crédito eletrônicos, a sua inserção nas relações comerciais, seus princípios e, principalmente, a ausência da cartulariedade, que gera a discussão sobre a possibilidade ou não da existência dessa modalidade de título de crédito

Ressalta-se que, ao se falar em títulos de crédito eletrônicos, logo se imagina a ausência de papel. Isso porque a autonomia e a literalidade não são atributos exclusivos de um documento material, podendo se manifestar de outras formas, que não a física. 
Vejamos: um documento eletrônico, assim como o físico, irá traduzir o seu valor através do seu conteúdo, ou seja, será regulado conforme a obrigação contida nele, de tal sorte que a literalidade estará presente, não obstante a forma eletrônica.

Da mesma forma, a um título de crédito eletrônico pode ser conferido o princípio da autonomia, tendo em vista que cada obrigação derivada do título, seja ele físico ou eletrônico, será sempre autônoma em relação às outras obrigações.

Diante dessas questões, conclui-se que o ponto crucial da discussão acerca dos títulos de crédito eletrônicos é a ausência da cartularidade, que será debatida ao longo desse capítulo.

\section{III.1. A desmaterialização dos títulos de crédito}

O Código Civil Brasileiro, oriundo da Lei $n^{\circ}$. 10.406/2002, trouxe, em seu Título VIII (arts. 887 a 926), as normas que regem os Títulos de Crédito.

Deve-se ressaltar que, tais normas são de caráter subsidiário, conforme disposto no art. $903^{29}$, que estabelece que as regras do novo Código somente serão aplicadas quando não houver lei especial, que regula as modalidades específicas dos títulos de crédito.

MARCOS PAULO FÉLIX DA SILVA ${ }^{30}$ enumera, claramente, os aspectos estruturais da regulamentação dos títulos de crédito no novo Código Civil:

\footnotetext{
${ }^{29}$ Art. 903. Salvo disposição diversa em lei especial, regem-se os títulos de crédito pelo disposto neste Código.

${ }^{30}$ SILVA, Marcos Paulo Félix da. Títulos de Crédito no Código Civil de 2002. Curitiba: Juruá, 2009. p. 127.
} 
"O novo Código contém uma disciplina geral para os títulos de crédito, com os seguintes objetivos primordiais: i) autorizar que um documento, presentes os requisitos legais imprescindíveis, seja reconhecido como um título de crédito atípico; ii) prestigiar a vontade jurídica manifestada livremente no seio as relações sociais mercantis; iii) servir de disciplina suplementar aos títulos de crédito típicos ou nominados, naquilo em que houver compatibilidade; iv) conferir aos títulos novos ou aos que vierem a ser criados uma disciplina referencial para a remissão, uma vez que, as leias específicas de vários títulos determinam que a eles se apliquem, quando cabíveis, subsidiária ou suplementarmente, as normas sobre as cambiais; e v) das 'respaldo aos títulos de crédito eletrônicos, emitidos por computador ou quaisquer meios técnicos ou eletrônicos (art. 889, §3º. c.c., art. 903)"” (grifos do original)

Como visto, uma das inovações do Código Civil de 2002 é a adoção do princípio da liberdade de criação e emissão dos títulos de crédito, admitindo a figura dos títulos atípicos ou inominados. Cabe aqui transcrever as palavras do Ministro aposentado do Superior Tribunal de Justiça, FRANCISCO CLÁUDIO E ALMEIDA SANTOS ${ }^{31}$, a respeito da relevância dos princípios na ciência jurídica:

\begin{abstract}
"Os princípios constituem os fundamentos de todas as ciências, e esse truísmo não poderia deixar de ser reconhecido na ciência jurídica. São eles os alicerces e as pilastras, nos quais se assenta todo o sistema jurídico. Daí a importância de seus enunciados e de suas interpretações corretas, pelo menos daqueles que de forma ostensiva e absoluta orientam a conduta dos agentes nas relações jurídicas e na geração, interpretação e aplicação dos atos e da normatividade pertinente.

$\mathrm{Na}$ verdade, é de tal intensidade sua importância que qualquer ato, ato, ou mesmo regra simples de direito, no confronto com um princípio, cessa sua efetividade, ou sofre restrições, de modo a se coadunar com o vetor principal."
\end{abstract}

Os títulos atípicos ou inominados são aqueles documentos que não são previstos, originalmente, na legislação, mas são compreendidos nos princípios reguladores dos títulos típicos ou nominados. Já os títulos nominados são popularmente conhecidos, tendo em vista que são regulados por leis específicas.

O art. 889 do CC é o que melhor contempla o princípio da liberdade de criação dos títulos atípicos. Veja-se:

\footnotetext{
31 Apud. SILVA, Marcos Paulo Félix da. Títulos de Crédito no Código Civil de 2002. Curitiba: Juruá, 2009. p. 67.
} 
“Art. 889. Deve o título de crédito conter a data da emissão, a indicação precisa dos direitos que confere, e a assinatura do emitente.

$\S 1^{\circ}$ É à vista o título de crédito que não contenha indicação de vencimento.

$\S 2^{\circ}$ Considera-se lugar de emissão e de pagamento, quando não indicado no título, o domicílio do emitente.

$\S 3^{\circ} \mathrm{O}$ título poderá ser emitido a partir dos caracteres criados em computador ou meio técnico equivalente e que constem da escrituração do emitente, observados os requisitos mínimos previstos neste artigo."

Ora, se não fosse a intenção do legislador de permitir o uso de títulos atípicos, não existiria razão para o art. 889 estabelecer os requisitos que um título de crédito deve conter.

Assim, o Código Civil deverá regular os títulos atípicos e, de forma subsidiária, as eventuais lacunas que as legislações especiais - aquelas que regem os títulos nominados - apresentarem.

Esta flexibilidade, prevista pelos legisladores, possibilitou a criação de novas relações jurídicas em relação aos títulos de crédito, não existindo mais as fortes barreiras formalísticas presentes em suas características.

Dessa forma, é imprescindível observar o $\S^{\circ}$ do art. 889, que assim leciona:

" $\S 3^{\circ} \mathrm{O}$ título poderá ser emitido a partir dos caracteres criados em computador ou meio técnico equivalente e que constem da escrituração do emitente, observados os requisitos mínimos previstos neste artigo."

Essa norma, com certeza, é a maior mudança presente no Código Civil de 2002, em relação aos títulos de crédito. Diante dessa novidade, muitos juristas passaram a defender que esse artigo passou a disciplinar o título eletrônico ou virtual. MARIA BERNARDETE MIRANDA é bem direta ao afirmar que "no $\$ 3 .^{\circ}$ do art. 889 do novo Código, encontramos os títulos eletrônicos ou escriturais, que são aqueles criados a partir dos 
caracteres em computador ou outro meio técnico equivalente e que constem de escrituração do emitente." 32

Porém, cabe esclarecer que, esse dispositivo não surgiu para pacificar a discussão acerca dos títulos de crédito eletrônico. E sim, para admitir a emissão de títulos independente de padronização, desde que observados os requisitos legais do art. 889.

Diante dessa inovação e, como já visto no capítulo anterior, surgiu uma questão de extrema relevância jurídica: como se dará a assinatura nos títulos eletrônicos? Isso porque, se o legislador efetivamente tivesse legislado acerca dos títulos eletrônicos, ele deveria ter disciplinado a assinatura digital, coisa que não fez, pois como se observa do caput do art. 889, "Deve o título de crédito conter a data da emissão, a indicação precisa dos direitos que confere, e a assinatura do emitente" (grifos nossos).

É claro que se pode entender que a assinatura prevista no art. 889 pode ser, também, a digital. Porém, existe uma corrente de juristas que busca disciplinar a assinatura digital, de modo que, se o legislador já tivesse legislado acerca dessa modalidade de assinatura, não haveria lógica a existência desse movimento.

Cabe aqui mencionar que a inovação trazida pelo art. $889, \S 3$ do CC está altamente relacionada aos avanços da informática, que acabou por ocasionar um fenômeno que gerou grandes impactos em diversos segmentos da sociedade. Esse fenômeno é a desmaterialização ou o abandono do papel, em todo ou em parte.

\footnotetext{
${ }^{32}$ MIRANDA, Maria Bernadete. "O Título de Crédito Eletrônico no novo Código Civil". Disponível em 〈http://www.saraivajur.com.br/menuEsquerdo/doutrinaArtigosDetalhe.aspx?Doutrina=270> Acesso em 01 maio 2009.
} 
Da obra de MARCOS PAULO FÉLIX DA SILVA ${ }^{33}$, colhe-se a seguinte explicação:

"Vivemos numa época de desmaterialização dos meios documentais e ingressamos sem retorno na progressiva dimensão do horizonte plasmado na tecnologia, em que os contornos das operações bancárias são instrumentalizados em poucos segundos, com alto grau de certeza e confiabilidade."

O setor bancário é, certamente, um dos segmentos que mais demonstrou o desejo de promover a substituição do suporte papel pelo suporte eletrônico. Isso porque, como bem elucida MARCOS PAULO FÉLIX DA SILVA, “a circulação física de documentos é vista, mormente no mercado bancário global, como sinônimo de atraso e de custo operacional",34.

Por fim, vale mencionar que, devido ao surgimento dos títulos de crédito atípicos ou inominados, dentre eles os títulos de crédito eletrônicos, muitos juristas, atentos às tendências e modificações motivadas pelo fenômeno da desmaterialização, afirmam que o instituto do título de crédito está em crise "porque não serviria mais para atender aos anseios dos novos sistemas de pagamentos, aprimorados como uso do computador", enquanto outros doutrinadores entendem que "já seria a hora de repensar o instituto dos títulos de crédito, em virtude da substituição crescente dos papéis pelos registros eletrônicos de informação" ${ }^{\text {35. }}$.

\section{III.2 Definição de título de crédito eletrônico}

Como já visto, foi adotado no novo Código Civil, o princípio da liberdade de criação e emissão de títulos atípicos ou inominados. Dessa forma, surgiu uma nova categoria de documentação de negócios jurídicos,

\footnotetext{
${ }^{33}$ SILVA, Marcos Paulo Félix da. Op. cit., p. 126.

${ }^{34}$ SILVA, Marcos Paulo Félix da. Op. cit., p. 127.

${ }^{35}$ SILVA, Marcos Paulo Félix da.. Op. cit., p. 127.
} 
desprovida das mesmas vantagens jurídicas oferecidas pelos títulos de crédito disciplinados por leis especiais.

Assim, com a novidade introduzida pelo $\S 3^{\circ}$, do art. 889 , que pode ser aplicada aos títulos típicos e atípicos, ficou normatizada a emissão de títulos de crédito eletrônicos, ou seja, aqueles emitidos "a partir dos caracteres criados em computador ou meio técnico equivalente", desde que observadas das regras do caput do referido artigo.

Antigamente para se fazer uma cobrança bancária, esta deveria ser faturada, depois seria emitida duplicata, seria preenchida uma nota, que seria encaminhada à Instituição Financeira para assim, dar início ao processo de cobrança.

Atualmente, grande parte dos serviços é realizada on-line. Os títulos são eletrônicos ou escriturais e tudo é feito via sistema, com uma rapidez incrível. A empresa fatura, porém não emite papéis. A nota é eletrônica, onde os dados do faturamento são importados através de uma conexão com os computadores do Banco, usando-se um software de comunicação computador a computador. Conectada, a empresa envia os arquivos eletrônicos para o Banco, que os recebe, diretamente em um centro de processamento, processa, emite as papeletas de cobrança e expede para os sacados.

Ocorre que, esse título será considerado um título de crédito atípico, também chamado de inominado e, conforme defendem muitos juristas, não contará com força executiva para a sua cobrança. Um título de crédito para valer como tal, deve obedecer a determinadas formalidades previstas na legislação e a esse conjunto de regras legais denominamos de rigor cambiário. 
FABIO ULHOA COELHO, define o título de crédito eletrônico como "o documento eletrônico representativo de direito autônomo ao recebimento de quantia líquida",36.

Diante dessa definição, percebe-se que o conceito de título de crédito eletrônico não carrega, por si só, muita inovação. Na verdade, os títulos de crédito eletrônicos representam uma modernização do tradicional Direito Cambiário, merecendo a ampliação de alguns conceitos, de forma a acolher as suas inovações.

Porém, não obstante a chancela legal que autoriza a emissão do título de crédito eletrônico, a sua cobrança judicial executiva passou a ser contestada sob o argumento de que o documento eletrônico não possuía um dos requisitos fundamentais para sua validade: a cartularidade.

\section{III.3. Os princípios eletrônicos e o título de crédito eletrônico}

Sabe-se que são três os princípios do Direito Cambiário: literalidade, autonomia e cartularidade. A literalidade e a cartularidade estão associadas ao papel, embora não no mesmo grau, tendo em vista que a literalidade pode, também, se manifestar de diferentes maneiras, inclusive nos documentos eletrônicos.

Dessa forma, o único princípio a se conservar sem nenhuma alteração é o da autonomia, que representa a garantia de que cada obrigação, que deriva do título, é autônoma em relação às demais, sendo essa certeza que garante a circulação dos títulos de crédito.

\footnotetext{
${ }^{36}$ COELHO, Fábio Ulhoa. Títulos de Crédito Eletrônicos. Revista dos Advogados, São Paulo, $\mathrm{n}^{\circ}$. 96, mar. 2008, p. 44.
} 
Isso significa que, o terceiro que vier a participar da relação cambial não será atingido por vícios já existentes na relação anterior. Ou seja, não é lícito ao devedor opor exceções de natureza pessoal àquele contra quem não estabeleceu relação direta.

Assim, a autonomia existe independentemente da forma como o crédito é representado - papel ou registro eletrônico - inexistindo qualquer impedimento à circulação do título de crédito eletrônico.

Em relação à literalidade, que é a expressão do conteúdo de um título, esta também estará presente nos títulos eletrônicos, pois irá abrigar uma obrigação capaz de ser exigida e cumprida. Porém, esse princípio merece um pouco de atenção, pois ele terá que ser ajustado ao suporte eletrônico.

FABIO ULHOA COELHO ${ }^{37}$ é quem melhor interpreta esse princípio em relação aos títulos de crédito eletrônicos. Veja-se:

"Já o Princípio da Literalidade, pelo qual não produzem efeitos cambiários os atos que não constam do teor do título de crédito, encontra equivalência no novo suporte. O que não há no registro eletrônico, não há no mundo - será o brocardo daqui para a frente. Quer dizer, quando tiver o título de crédito suporte eletrônico, não produzirá efeitos cambiais, por exemplo, o aval concedido num instrumento papelizado. O Princípio da Literalidade não desaparecerá, como o da Cartularidade, mas deverá ser ajustado ao suporte eletrônico.

Graças à preservação do Princípio da Autonomia e ao ajuste do da Literalidade, a cambial eletrônica continuará a cumprir a mesma função de facilitar a agilização e mobilização do crédito comercial que vinham cumprindo satisfatoriamente os títulos papelizados desde sua criação na Idade Média." (grifos do original)

Conclui-se, então, no que tange aos princípios da autonomia e da literalidade, a transmutação do suporte não traz consigo nenhuma conseqüência capaz de gerar um impasse jurídico. Não se pode esquecer, porém, que o princípio da literalidade deverá se adequar ao suporte 
eletrônico, diferentemente do princípio da cartularidade que tenderá a sumir quando se trata de titulo de crédito eletrônico

Isso se deve porque, obviamente, o princípio da cartularidade não tem como se ajustar ao meio eletrônico, pois se pressupõe a posse de um documento, para o exercício do direito nele mencionado.

Sobre o tema, LUIZ EMYGDIO ROSA JR. ${ }^{38}$ assim escreve:

"Os avanços tecnológicos têm demonstrado a necessidade de se repensar a doutrina sobre a cartularidade ou a incorporação, como, ocorre, por exemplo, com os cartões de banco com tarja magnética, que permitem a retirada de dinheiro da conta-corrente bancária em substituição ao cheque. O mesmo ocorre com as duplicatas virtuais, correspondentes a registros eletromagnéticos transmitidos via computador por empresário ao banco, que, também através do computador, pode processar a cobrança ao devedor"

Veja-se o que ensina $\mathrm{BORBA}^{39}$ quando se refere à cartularidade:

"A cártula seria o documento essencial para o exercício do crédito que o título consubstanciaria. Desta forma, para que se ingressasse com uma ação cambial ou mesmo para que tão-somente se cobrasse o crédito, seria necessário apresentar o título, corporificado na cártula.

Não havia qualquer possibilidade de se provar e quantificar a dívida cambiária por outro meio e, então, passar a cobrá-la cambialmente, vez que esta cobrança dependia, de maneira imprescindível, da existência e apresentação da cártula. Mesmo no caso de perda ou destruição do título, situação para a qual existe a ação de recuperação de título ao portador, observe-se que se deve constituir um novo título, para só então tornar-se possível a cobrança por via cambial."

Assim, a validade de um título de crédito emitido por um meio eletrônico, com a conseqüente ausência de cártula, é a grande problemática apresentada nesse tema.

\footnotetext{
${ }^{37}$ COELHO, Fábio Ulhoa. Títulos de Crédito Eletrônicos. Revista dos Advogados, São Paulo, ${ }^{\circ}$. 96, mar. 2008, p. 46.

${ }^{38}$ ROSA JUNIOR, Luiz Emygdio Franco da. Op. cit., p. 66.
} 
FÁBIO ULHOA COELHO ${ }^{40}$, já se manifestou acerca dessa questão:

"O Princípio da Cartularidade, que pressupõe a posse do documento para o exercício do direito nele mencionado, não se ajusta ao ambiente eletrônico. Não há equivalente possível entre a posse física do pedaço de papel em que se lançavam as informações sobre o crédito e qualquer relação de fato do credor com os registros eletrônicos em que elas se assentam no novo suporte. $\mathrm{O}$ Princípio da Cartularidade se destinava a impedir a cobrança do título por quem não fosse mais o seu titular, por força de endosso anteriormente praticado. Como o documento eletrônico sempre incorporará a informação atualizada sobre a titularidade do crédito, não há risco de o antigo credor apresentar-se como sendo ainda o titular do direito. Em nada se preocupa, assim, o fim do Princípio da Cartularidade."

Ressalta-se que, nem todos os juristas concordam com a afirmação do notável professor ULHOA, quando ele afirma que o fim do princípio da cartularidade não traz nenhuma preocupação. Ao contrário, é essa é a grande controvérsia que ronda os títulos de crédito eletrônicos.

Porém, diante dessas colocações e considerando o que já foi tratado anteriormente acerca do fenômeno da desmaterialização dos títulos de crédito, é possível dizer que a inclusão de um direito em um documento, permanece, mesmo que sob a forma eletrônica e, com isso, supera-se o entrave da dogmática jurídica referente ao princípio da cartularidade.

Não é demais lembrar que, diante das necessidades impostas por um mercado globalizante, sobretudo no sistema financeiro, a rapidez dos negócios, inclusive aqueles realizados através dos títulos de crédito, exigiu o desenvolvimento de modelos que atendessem as expectativas dos comerciantes, modelos estes que foram criados face ao surgimento das modernas tecnologias propiciadas pela informática.

\footnotetext{
${ }^{39}$ BORBA, Gustavo Tavares. A desmaterialização dos títulos de crédito. Disponível em $\langle$ http://www.borbaadvogados.com.br/public5.pdf> Acesso em 16 maio 2009.

${ }^{40}$ COELHO, Fábio Ulhoa. Títulos de Crédito Eletrônicos. Revista dos Advogados, São Paulo, $\mathrm{n}^{\circ}$. 96, mar. 2008, p. 46.
} 
A ausência de cártula, em documentos constitutivos de direito, já é uma realidade nas relações comercias, a exemplo da duplicata virtual ou escritural, desenvolvida pelas instituições financeiras visando a simplificação da atividade de cobrança e operações de desconto bancário.

Como será dissecado no próximo capítulo, a duplicata virtual se constitui sem a emissão do papel. Embora ainda se discuta a natureza jurídica desse instrumento, tendo em vista que parte da doutrina não a reconhece como título de crédito, resta claro que a ausência do papel, não lhe retira o status de título de crédito.

Isso porque, como já mencionado, a falta da cártula não impede a incorporação do direito em um documento eletrônico, que dotado de autonomia e literalidade, é capaz de circular, promovendo, assim, a finalidade primordial dos títulos de crédito.

Porém, ainda que se possa sustentar a possibilidade de adequar o documento eletrônico dentro das normas hoje existentes, dificilmente o Poder Judiciário iria interpretar dessa forma os casos que the fossem submetidos. Sabemos que existe toda uma cultura tradicional, apegada ao direito positivo, de modo que, no sistema brasileiro, as novas teses de direito levam algum tempo para se cristalizar.

Nos casos dos títulos de crédito, há um notório incômodo da doutrina tradicional em aceitar novas leituras e interpretações em relação aos antigos princípios cambiários. Não bastasse isso, há também a necessidade de algumas alterações legislativas no sistema interno brasileiro.

A necessidade de alterações na legislação decorre da forma como vem se organizando o direito comparado e internacional, visando criar normas para regular o comércio eletrônico. 


\title{
III.4. Lacuna no ordenamento brasileiro
}

É possível concluir, após um breve estudo sobre os títulos eletrônicos, que o legislador brasileiro não trabalhou de modo devido o tema acerca da executividade e da eficácia dos documentos eletrônicos.

O regramento da ICP - Brasil é o único, no ordenamento pátrio, que trata sobre o documento eletrônico e que trata, restritamente, da assinatura digital. É certo que existem inúmeros projetos de lei tramitando no Congresso Nacional, no entanto, atualmente, não há nenhum documento legal que trate sobre o tema. Existe, então, uma lacuna legal.

De acordo com o art. $4^{0^{41}}$ da Lei de Introdução do Código Civil, a lacuna deve ser suprida por princípios gerais do direito. E foi, justamente neste contexto, que surgiu a importância do principio da equivalência funcional. O seu uso pode levar o magistrado "a dispensar o demandante que funda sua pretensão num documento eletrônico de qualquer outra prova não imposta aos que exibem documentos papelizados". ${ }^{42}$

\section{E é assim que se manifesta FABIO ULHOA COELHO ${ }^{43}$ :}

\begin{abstract}
"A petição inicial de execução da duplicata eletrônica pode, assim, ser instruída com o instrumento de protesto por indicações e relatório impresso noticiando a entrega da mercadoria, oriundo este de sistema eletrônico em que está armazenada a informação e no qual conste a certificação da assinatura digital do executado ou seu preposto. Isto porque a nenhuma informação pode ser negada eficácia, validade e executividade só pela circunstância de ter por suporte um meio eletrônico." (grifamos)
\end{abstract}

Assim, é imprescindível a utilização das técnicas existentes de execução dos títulos cartularizados, por intermédio da interpretação de

\footnotetext{
${ }^{41}$ Art. $4^{0}$. Quando a lei for omissa, o juiz decidirá o caso de acordo com a analogia, os costumes e os princípios gerais de direito.

${ }^{42}$ MARCANCINI, Augusto Tavares Rosa. Op. cit., p.08

${ }^{43}$ COELHO, Fábio Ulhoa. Títulos de Crédito Eletrônicos. Revista dos Advogados, São Paulo, no ${ }^{\circ}$. 96, mar. 2008, p. 46.
} 
princípios gerais de direito, em especial, o da equivalência funcional. Dessa forma, a solução proposta pelo ilustre professor FABIO ULHOA COELHO, por enquanto, parece a mais adequada, em razão da ausência de legislação sobre o tema. Consequentemente, a execução de um título de credito eletrônico seguirá, em razão do princípio da equivalência funcional, os mesmos ditames aplicáveis aos títulos de créditos em papel, até que a lacuna legislativa seja preenchida pelo legislador brasileiro, a exemplo do que tem ocorrido em outros países.

\section{III.5 Legislação estrangeira}

O direito material relacionado aos títulos de crédito, em grande número de países, signatários de convenções internacionais, é uniforme, sobretudo no que se refere aos títulos que integram o chamado "mercado popular", como, por exemplo, o cheque e a nota promissória.

Porém, com o crescimento do comércio eletrônico, novos tipos de contratos surgiram e muitos países passaram a criar legislações, para regular esse comércio, de acordo com um novo direito e novos princípios.

Como já visto, a regulamentação das assinaturas digitais representa um passo importante na legislação do comércio eletrônico, especialmente em relação ao Direito cambiário, pois possibilita a criação ou a emissão de um título de crédito e, inclusive, o uso de outros institutos próprios daquele direito, como o endosso.

Em relação aos títulos de crédito eletrônico, a França e a Alemanha são os países que possuem as legislações mais avançadas sobre o tema. 
$\mathrm{Na}$ França, o instituto foi recepcionado através da criação da Lettre de Change-Relevé, traduzida por NEWTON DE LUCCA, como a CambialExtrato. Veja-se o que diz NEWTON DE LUCCA ${ }^{44}$ sobre esse instituto:

\begin{abstract}
"Podia a Lettre de Change-Relevé, assumir duas diferentes formas: LCR-papel e LCR-fita magnética.

No caso da LCR-papel, a inovação básica consistia no fato de que o título de crédito não mais iria circular materialmente: após a remessa da LCR-papel ao banco do sacador, todos os dados eram transportados para uma fita magnética.

O título era conservado em poder do banco sacador. Passava a circular somente a fita magnética: do banco do sacador ao "computador da compensação" do Banco da França e, deste, para o banco do sacado. Somente no banco do sacado era que o papel reaparecia: o extrato da LCR (relevé).

Já no caso da LCR-fita magnética, a significação era, evidentemente, mais profunda. Sobre ela, assim se manifestava Michel Vasseur, especialmente ao referir-se à diferença entre a LCR-papel e a LCR-fita magnética.

'Um verdadeiro abismo' - tal era a expressão por ele utilizada posto que a primeira seria uma verdadeira letra de câmbio que, após a sua criação, era transportada para a fita magnética. A segunda não era nem jamais poderia ser considerada uma verdadeira letra de câmbio.

Arrematava esse jurista:

'A afirmação é evidente. Inexiste letra de câmbio sem a cártula, isto é, sem papel. Ora, a fita magnética exclui todo papel inicialmente redigido"'
\end{abstract}

Como visto, esse título apresentava duas modalidades distintas: LCR-papel e LCR-fita magnética. O LCR-papel é a modalidade que faz fronteira entre os títulos de crédito em sem modo usual e os eletrônicos. $\mathrm{O}$ LCR-fita magnética é a modalidade que apresenta a utilização dos títulos eletrônicos propriamente ditos, uma vez que toda a plataforma utilizada é eletrônica.

Há que se mencionar que, a Lettre de Change-Relevé foi criada em 1973, a partir de uma legislação especial, que depois veio a ser regulamentada pelo Código Civil Francês.

Já na Alemanha, o instituto teve a sua origem através da criação da Lastschriftverkerhr. Trata-se de um sistema de cobrança e não de desconto.

\footnotetext{
${ }^{44}$ LUCCA, Newton de. Títulos e Contratos Eletrônicos: O advento da Informática e seu impacto no mundo jurídico. In: LUCCA, Newton de; SIMÃO FILHO, Adalberto (Org.). Direito \& Internet. São Paulo: EDIPRO, 2000. p. 40.
} 
Ressalta-se, ainda, que na Alemanha, diferentemente da França e do Brasil, não ocorre a emissão de um título de crédito para documentar a compra e venda mercantil.

NEWTON DE LUCCA ${ }^{45}$ assim define esse instituto:

"A Lastschriftverkerhr (nota de débito) é um título de cobrança pelo qual o credor, por intermédio de um estabelecimento bancário, se ressarce da conta do devedor, no mesmo ou num outro banco, tendo como base:

a) uma ordem de débito outorgada pelo devedor a favor do credor;

b) uma autorização escrita outorgada pelo devedor em favor do credor de um lançamento a débito (autorização de cobrança).

$\mathrm{O}$ processo de pagamento é muito semelhante ao dos cheques. O credor entrega ao banco as notas de débito no dia em que ocorre o vencimento de seus créditos. Nelas constam o nome do credor, o nome do banco, o número das contas do credor e do devedor e a importância devida.

O banco irá creditar provisoriamente na conta de seu cliente a importância total das notas apresentadas, remetendo-as às agências que fazem a administração das contas de cada devedor. Se os devedores mantêm contas em outros estabelecimentos bancários, como é mais comum, as notas de débito são remetidas para as agências bancárias domiciliatárias de tais contas, diretamente ou, em outra hipótese, são enviadas por um banco correspondente ou agências de contabilidade que executem tal tipo de serviço.

O resgate das notas, efetivamente, só ocorrerá quando o banco (no qual o devedor mantém a sua conta), debitar a importância das mesmas na conta de cada devedor. A alusão a esse instrumento é necessária e mesmo indispensável posto que a Alemanha pode ser considerada um dos países precursores nos pagamentos por troca de fita magnética."

Ressalta-se que, tanto o modelo francês como o alemão se basearam na letra de câmbio para criar os institutos acima descritos. E foi, exatamente, por isso que encontraram uma barreira legislativa.

Cabe aqui citar um trecho transcrito por NEWTON DE LUCCA, que demonstra a necessidade de existir uma legislação específica para regular o trânsito de negócios firmados pela via eletrônica, enfatizando ao final que no Brasil, a técnica da duplicata eletrônica ou escritural, baseia tão somente no fator confiança. Veja-se:

\footnotetext{
${ }^{45}$ LUCCA, Newton de. Títulos e Contratos Eletrônicos: O advento da Informática e seu impacto no mundo jurídico. In: LUCCA, Newton de; SIMÃO FILHO, Adalberto (Org.). Direito \& Internet. São Paulo: EDIPRO, 2000. p. 40-41.
} 


\begin{abstract}
"As desvantagens da ausência de uma lei em tal sentido são evidentes. Enquanto na França, pelo desenvolvimento gradual e amadurecido das reflexões a propósito do tema, já existe uma lei, 1981 (Lei Dailly), de $n^{\circ}$. 81-I, de 2 de janeiro, regulamentada pelo Decreto $\mathrm{n}^{\circ}$. 81-862, de 9 de setembro do mesmo ano, conferindo até mesmo força executória para o borderô que acompanha as fitas magnéticas que tenham sido objeto de uma operação de desconto bancário, em nosso país a técnica da duplicata escritural repousa, fundamentalmente, no fator confiança." 46
\end{abstract}

Ocorre que, a necessidade da existência de uma legislação específica para as operações eletrônicas ainda é um assunto polêmico entre os juristas. Há quem defenda a tese de que a Internet é um meio de comunicação como qualquer outro e, portanto, não necessita de uma legislação própria. Outros, como o próprio NEWTON DE LUCCA, defendem que a legislação atual não é suficiente para englobar os novos casos que surgem com a Internet.

De fato, essa questão é muito polêmica, podendo ser defendida em ambos os aspectos, já que é possível sustentar a validade jurídica dos documentos eletrônicos através da interpretação da legislação atualmente vigente, utilizando-se os princípios gerais do direito, dentre eles a equidade e a analogia.

\footnotetext{
${ }^{46}$ LUCCA, Newton de. Títulos e Contratos Eletrônicos: O advento da Informática e seu impacto no mundo jurídico. In: LUCCA, Newton de; SIMÃO FILHO, Adalberto (Org.). Direito \& Internet. São Paulo: EDIPRO, 2000. p. 43.
} 


\title{
IV. A Duplicata Cartular e a Duplicata Virtual
}

A Duplicata é um título de crédito genuinamente brasileiro, e sua história é relativamente nova em comparação com outros títulos de créditos, como as letras de cambio e as notas promissórias.

Ela é regulada pela Lei $\mathrm{n}^{0}$. 5.474/68 e, subsidiariamente, pela legislação sobre a letra de câmbio, "em razão da semelhança de estrutura entre esses dois títulos e porque o legislador desejou conferir à duplicata as garantias básicas de endossabilidade e de inoponibilidade de exceção pelo devedor perante o terceiro de boa-fê,47.

LUIZ EMYGDIO ROSA JR. ${ }^{48}$ conceitua a duplicata como:

\begin{abstract}
"Título de crédito formal, impróprio, causal, à ordem, extraído por vendedor, ou prestador de serviços, que visa a documentar o saque fundado sobre crédito decorrente de compra e venda mercantil ou prestação de serviços, assimilada aos títulos cambiários por lei, e que tem como seu pressuposto a extração de fatura."

É preciso observar que a duplicata não é um título de crédito obrigatório quando se há uma relação comercial, no entanto, é a duplicata o único título válido para comprovar que houve um saque de vendedor por certa quantia, em relação ao comprador referente àquela relação jurídica.
\end{abstract}

Nesse capítulo, serão abordados os aspectos mais relevantes da duplicata virtual e o seu impacto nas relações comerciais.

Primeiramente, serão elucidados os principais aspectos da duplicata, seus requisitos e suas características.

\footnotetext{
${ }^{47}$ ROSA JUNIOR, Luiz Emygdio Franco da. Op. cit., p. 661.

${ }^{48}$ ROSA JUNIOR, Luiz Emygdio Franco da. Op. cit., p. 673.
} 
Depois, será apresentado o modelo tradicional, ou seja, como se opera o saque, o aceite e a liquidação da duplicata mercantil cartularizada, sem a incidência do fenômeno da desmaterialização. Na seqüência, demonstrar-se-á como se operam as mesmas transações com duplicatas, agora sob o efeito da desmaterialização. Vistos os modelos, haverá condições de caracterizar claramente a duplicata virtual.

$\mathrm{Na}$ análise desses modelos, deve-se observar que, apesar dos mesmos representarem transações de compra e venda e, portanto, referirem-se a saques de duplicatas mercantis, são, em parte, aplicáveis às duplicatas de prestação de serviços. Evidentemente, as duas espécies do título diferem quanto à causa autorizadora do saque. Logo, em relação às duplicatas de prestação de serviço, deve-se desconsiderar a representação do pedido de compra e da entrega da mercadoria. Entretanto, as representações relativas à remessa, aceite, devolução, cobrança, pagamento e protesto, são válidas.

\section{IV.1. Aspectos da duplicata}

Os requisitos da duplicata estão previstos nos artigos $1^{\circ}, \S 1^{\circ}$ e $2^{\circ}, \S 1^{\circ}$ da Lei $n^{\circ} .5 .474 / 68$, que apresentam os seguintes dispositivos:

\footnotetext{
“Art . 10 Em todo o contrato de compra e venda mercantil entre partes domiciliadas no território brasileiro, com prazo não inferior a 30 (trinta) dias, contado da data da entrega ou despacho das mercadorias, o vendedor extrairá a respectiva fatura para apresentação ao comprador.

$\S 1^{\circ}$ A fatura discriminará as mercadorias vendidas ou, quando convier ao vendedor, indicará somente os números e valores das notas parciais expedidas por ocasião das vendas, despachos ou entregas das mercadorias.

Art . $2^{\mathbf{o}}$ No ato da emissão da fatura, dela poderá ser extraída uma duplicata para circulação como efeito comercial, não sendo admitida qualquer outra espécie de título de crédito para documentar o saque do vendedor pela importância faturada ao comprador.

$\S 1^{\circ}$ A duplicata conterá:

I - a denominação "duplicata", a data de sua emissão e o número de ordem;
} 
II - o número da fatura;

III - a data certa do vencimento ou a declaração de ser a duplicata à vista;

IV - o nome e domicílio do vendedor e do comprador;

$\mathrm{V}$ - a importância a pagar, em algarismos e por extenso;

VI - a praça de pagamento;

VII - a cláusula à ordem;

VIII - a declaração do reconhecimento de sua exatidão e da obrigação de pagá-la, a ser assinada pelo comprador, como aceite, cambial;

IX - a assinatura do emitente."

É importante salientar que, o vendedor não está obrigado a emitir duplicata em todas as vendas a prazo que realiza, contudo está impedido de emitir qualquer outro título, como preceitua o art. $2^{\circ}$ da Lei $n^{0} 5.474 / 68$. A apresentação da duplicata ao comprador se dará no ato da entrega da mercadoria ou logo após.

Conforme prevê a Lei ${ }^{0} 5.474 / 68$, o emitente tem até 30 (trinta) dias a contar de sua emissão para enviá-la ao devedor e, este, ao recebê-la terá 10 (dez) dias para devolvê-la assinada ou declarar, por escrito, os motivos da recusa.

$\mathrm{O}$ aceite da duplicata vem a ser a assinatura da duplicata, reconhecendo a validade do crédito do vendedor, ou seja, reconhecendo o devedor a sua própria dívida, ou ainda, recusá-la pelos motivos previstos em lei.

$\mathrm{Na}$ falta do aceite, é possível supri-lo com o protesto ou, ainda, com o comprovante de entrega de mercadoria ou da prestação de serviço realizado, que, quase sempre, é o canhoto de recebimento da nota fiscal, como expressa a súmula do STJ $\mathrm{n}^{\circ}$. 248 , “comprovada a prestação de serviços, a duplicata não aceita, mas protestada, é título hábil para instituir pedido de falência

$\mathrm{O}$ artigo $8^{\circ}$ da lei das Duplicatas enumera os motivos para a recusa do aceite. Veja-se: 
“Art. $\mathbf{8}^{\circ} \mathrm{O}$ comprador só poderá deixar de aceitar a duplicata por motivo de:

I. Avaria ou não recebimento das mercadorias, quando não expedidos ou não entregues por sua conta e risco;

II. Vícios, defeitos, e diferenças na qualidade ou quantidade das mercadorias, devidamente comprovados;

III. Divergências nos prazos ou nos preços ajustados."

Sabe-se que o pagamento é a principal forma de extinção da obrigação contida no titulo de crédito. Mas esta não se encerra somente com o pagamento do mesmo, e sim, com o resgate deste, com a assinatura do portador, dando a quitação plena, total e irrestrita. Quanto ao protesto das duplicatas, ele se dará somente por falta de aceite, de devolução ou de pagamento, conforme preceitua o art. $13^{49}$ da Lei das Duplicatas.

Os três principais princípios dos títulos de crédito também são aplicáveis às duplicatas. Porém, a duplicata contém um requisito único, que a diferencia dos demais títulos de crédito: a causalidade.

A causalidade da duplicata diz respeito ao fato de que esta nunca irá existir de maneira independente, como é o cheque e a nota promissória, mas sim, sob uma condição, uma causa, que é o crédito de uma relação mercantil ou de uma prestação de serviço. Nos dizeres de LUIZ EMYGDIO ROSA JR. ${ }^{50}$ :

"A doutrina é pacífica ao não considerar a duplicata como título de crédito
próprio porque não consubstancia operação de crédito, mas decorre de causas
predeterminadas em lei: compra e venda mercantil ou prestação de serviços.
Assim, a duplicata corresponde a título de crédito impróprio, ou imperfeito, ou
cambiariforme, porque: a) visa a documentar o saque pelo vendedor da
importância faturada ao comprador da mercadoria ou o saque pelo prestador do

${ }^{49}$ Art. 13. A duplicata é protestável por falta de aceite de devolução ou pagamento.

$\S 1^{\circ}$ Por falta de aceite, de devolução ou de pagamento, o protesto será tirado, conforme o caso, mediante apresentação da duplicata, da triplicata, ou, ainda, por simples indicações do portador, na falta de devolução do título

$\S 2^{\circ} \mathrm{O}$ fato de não ter sido exercida a faculdade de protestar o título, por falta de aceite ou de devolução, não elide a possibilidade de protesto por falta de pagamento.

$\S 3^{\circ} \mathrm{O}$ protesto será tirado na praça de pagamento constante do título.

$\S 4^{\circ} \mathrm{O}$ portador que não tirar o protesto da duplicata, em forma regular e dentro do prazo de 30 (trinta) dias, contado da data de seu vencimento, perderá o direito de regresso contra os endossantes e respectivos avalistas

${ }^{50}$ ROSA JUNIOR, Luiz Emygdio Franco da. Op. cit., p. 674-675. 
serviço pela importância faturada ao beneficiário; b) tem natureza causal por estar legalmente vinculada, como cordão umbilical, à sua origem, uma vez que só pode ser extraída em decorrência da compra e venda mercantil ou de prestação de serviços, não sendo, portanto, título abstrato ou perfeito." (grifos nossos)

Assim, admitir a falta da causalidade implica em dizer que a duplicata emitida não está de acordo com a lei, prática considerada como crime.

\section{IV.2. O modelo tradicional}

A duplicata mercantil, na condição de título de crédito com causa de emissão determinada por lei, só pode ser sacada para representar crédito proveniente de um contrato de compra e venda. Para entender a duplicata virtual, deve-se, primeiro, ter em mente, como é o procedimento do saque da duplicata mercantil.

A Figura 1 representa o modelo tradicional de saque de duplicata mercantil. Na representação, supõe-se que o contrato de compra e venda tenha se originado a partir de um pedido remetido pelo comprador ao vendedor, mas esta origem poderia ser diversa. Por exemplo, o negócio poderia ter nascido de uma proposta do vendedor ao comprador, com a posterior anuência deste.

Supõe-se também, para simplificação do modelo, que o comerciante vendedor tenha adotado o sistema de Nota Fiscal-Fatura (NFF) e que tenha sido sacada uma única duplicata para representar todo o valor da venda, com vencimento em parcela única.

Assim, entregue a mercadoria, juntamente com a Nota Fiscal-Fatura, o vendedor emite a duplicata (em papel) e efetua o respectivo lançamento no Livro de Registro de Duplicatas. Em seguida, envia a duplicata 
cartularizada para aceite do comprador. O comprador (devedor) recebe a duplicata, apõe seu aceite e a devolve ao vendedor (credor). No vencimento, o devedor paga ao credor e recebe a cártula quitada. Este é o modelo mais simples. Veja-se:

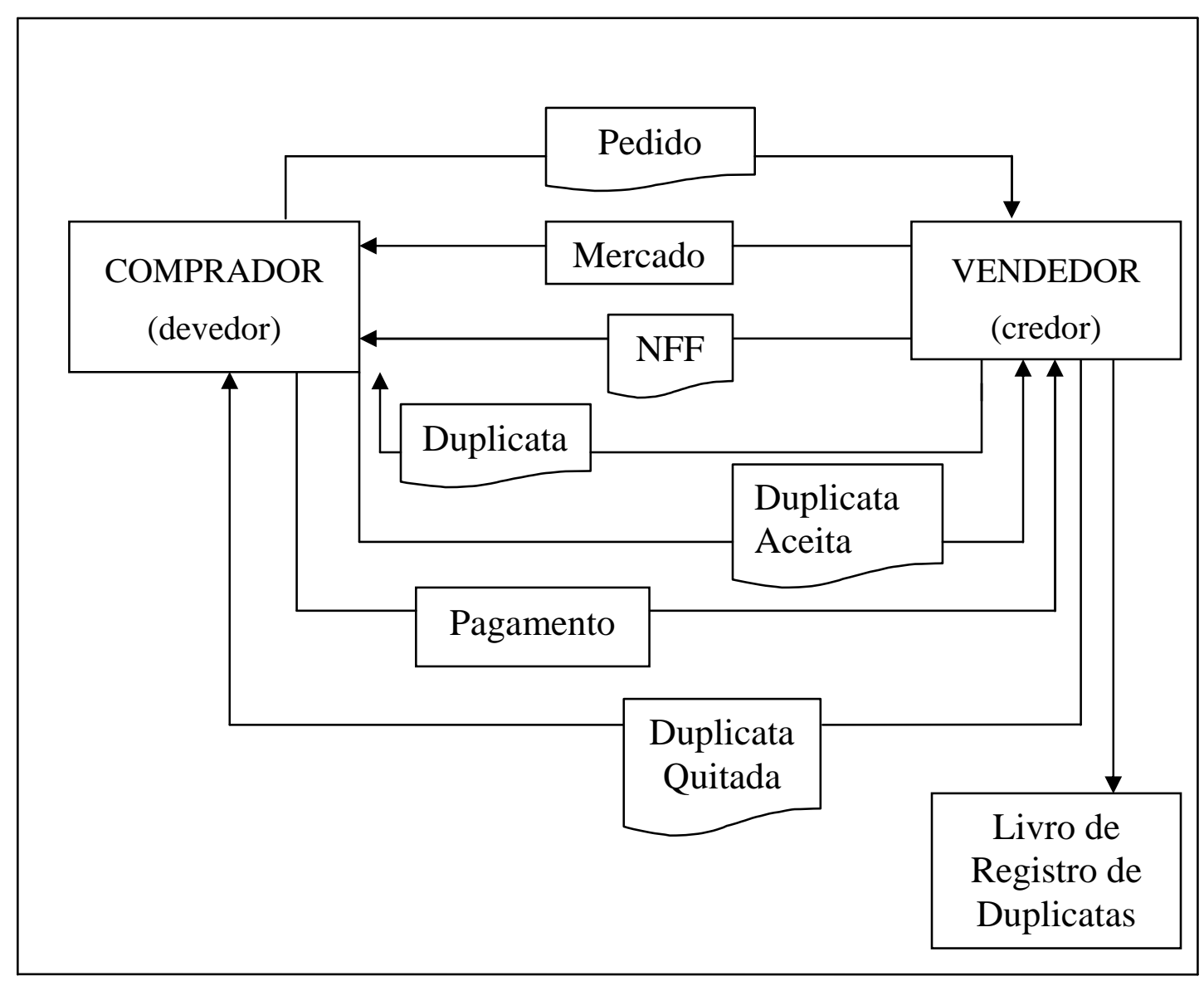

Figura 1

Ressalta-se que, esse é o modelo mais simples em relação ao saque da duplicata. Isso se deve à possibilidade da circulação das duplicatas através do endosso, como por exemplo, quando o comerciante-vendedor decidir endossar a duplicata para uma instituição bancária, que efetuará a cobrança do mesmo, no seu vencimento.

Nesta hipótese, após receber a duplicata aceita pelo compradordevedor, o vendedor a endossa e envia ao banco. O banco por sua vez, emite um "Aviso de Cobrança" ou, como é mais conhecido, um "Boleto 
Bancário", que contém indicações sobre o título, tais como número da fatura, número de ordem, valor e data do vencimento. De posse do boleto, o devedor efetua o pagamento em qualquer agência bancária.

Se houver o inadimplemento, ou seja, se o devedor não realizar o pagamento, o credor pode levar a duplicata à execução perante o Poder Judiciário. Isso porque, a duplicata aceita constitui-se em título executivo extrajudicial, suficiente para instruir um processo de execução.

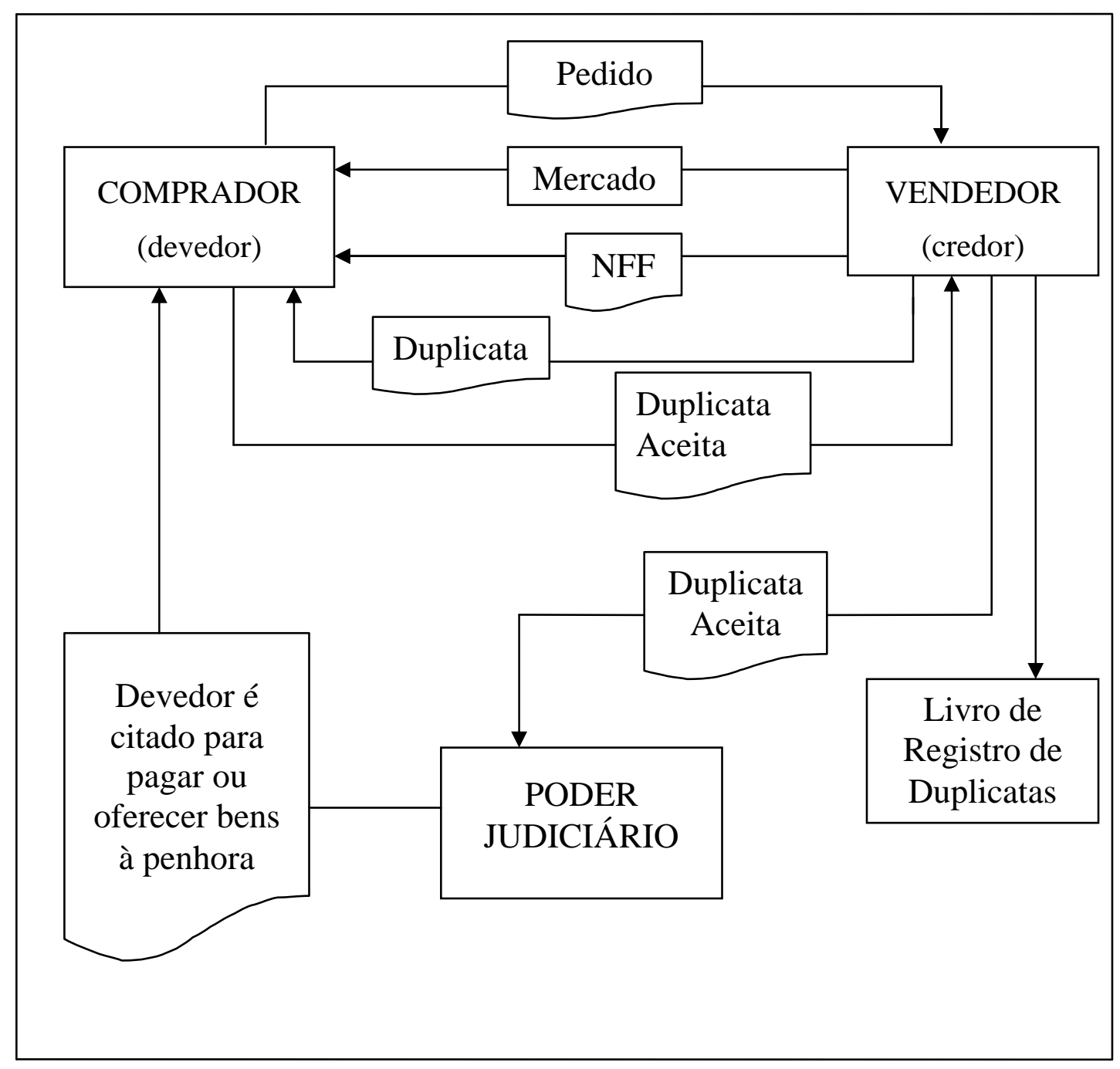

Figura 2

No entanto, se o devedor reteve a duplicata, a execução depende de prévio protesto por indicações e da comprovação da entrega e do recebimento da mercadoria. Registra-se que, existem outros modelos que 
representam a circulação da duplicata, porém, por razões de objetividade, iremos diretamente para análise do modelo virtual, desmaterializado, objeto do presente trabalho.

\section{IV.3. A duplicata virtual}

Duplicata virtual ou escritural é o nome designado às duplicatas sem a materialização cartular, ou seja, toda a sua tramitação ocorre por meios eletrônicos, sem que haja a sua impressão física.

A sua criação se deve ao fato que o legislador, ao instituir a Lei das Duplicatas, teve que flexibilizar as suas normas, uma vez que afastou os rigores e formalismos tradicionais do direito cambiário, criando facilitadores para a documentação, circulação e cobrança do crédito concedido nas vendas a prazo.

Veja-se agora, nas palavras de MARCOS PAULO FÉLIX DA SILVA $^{51}$, como é o procedimento da duplicata virtual:

"Eis a síntese do mecanismo: o credor (descontário) assume contratualmente a responsabilidade pela existência da compra e venda mercantil ou da prestação de serviços; o registro dos dados das duplicatas pode ser feito em campos predeterminados no site da instituição financeira, a partir dos quais são enviados via internet para o descontador (banco); o valor líquido apurado do desconto é creditado na conta corrente do credor (descontário), dentro das condições e prazo previstos no contrato.

Por sua vez, o banco emite bloqueto de cobrança para cada duplicata escritural descontada, para que o sacado realize o respectivo pagamento. Na falta de pagamento dos créditos, o banco remete ao cartório de protesto - em disquetes ou por transmissão eletrônica - as indicações dos dados das duplicatas, a partir das quais o cartório expedirá a intimação do devedor; não havendo pagamento no prazo legal para tal, o Tabelião lavrará e registrará o protesto, expedindo-se, outrossim, o instrumento de protesto por indicações, a ser entregue ao apresentante."

\footnotetext{
${ }^{51}$ SILVA, Marcos Paulo Félix da. Op. cit., p. 135.
} 
Resumindo: a prática de saque da duplicata mercantil, agora sob a influência do fenômeno da desmaterialização, parte-se novamente do pedido de compra enviado pelo comprador ao vendedor. Muitas vezes, o próprio pedido de compra já é desmaterializado, conforme será representado na Figura 3, sendo transmitido por EDI (Eletronic Data Interchange - troca eletrônica de dados). No entanto, se o pedido for materializado em um papel, nenhum efeito haverá sobre a prática do saque da duplicata virtual.

Recebido o pedido, o vendedor despacha a mercadoria, juntamente com a obrigatória Nota Fiscal-Fatura. A Nota Fiscal-Fatura, necessariamente, será impressa em papel, pois, para fins fiscais, deve acompanhar a mercadoria. O vendedor, então, simultaneamente à emissão da Nota Fiscal-Fatura, gera, em seus computadores, um registro com as informações da duplicata mercantil que representa o seu crédito. Ao mesmo tempo, é efetuado um lançamento, também informatizado, no Livro de Registro de Duplicatas ${ }^{52}$.

Posteriormente, o vendedor envia as informações relativas à duplicata, por EDI, ao banco, para que seja efetuada a cobrança. Note-se que não é possível falar na ocorrência de endosso, pois não há o lançamento desse ato cambiário no título desmaterializado. Normalmente, o que existe é um contrato de prestação de serviços de cobrança, entre o comerciante e o banco, sendo que este é remunerado pela quantidade de títulos cobrados. O banco, então, a partir do registro em seus computadores, emite, em papel, o respectivo boleto para cobrança, que é remetido ao devedor.

\footnotetext{
${ }^{52}$ A Lei das Duplicatas expressamente permite que o Registro de Duplicatas seja "substituído por qualquer sistema mecanizado" (Lei 5.474/68, art. 19, § $3^{\circ}$ ).
} 
Supondo-se o adimplemento, o devedor, no vencimento, vai a uma agência bancária e paga o boleto, recebendo sua quitação. O banco, então, efetua um crédito na conta corrente do credor.

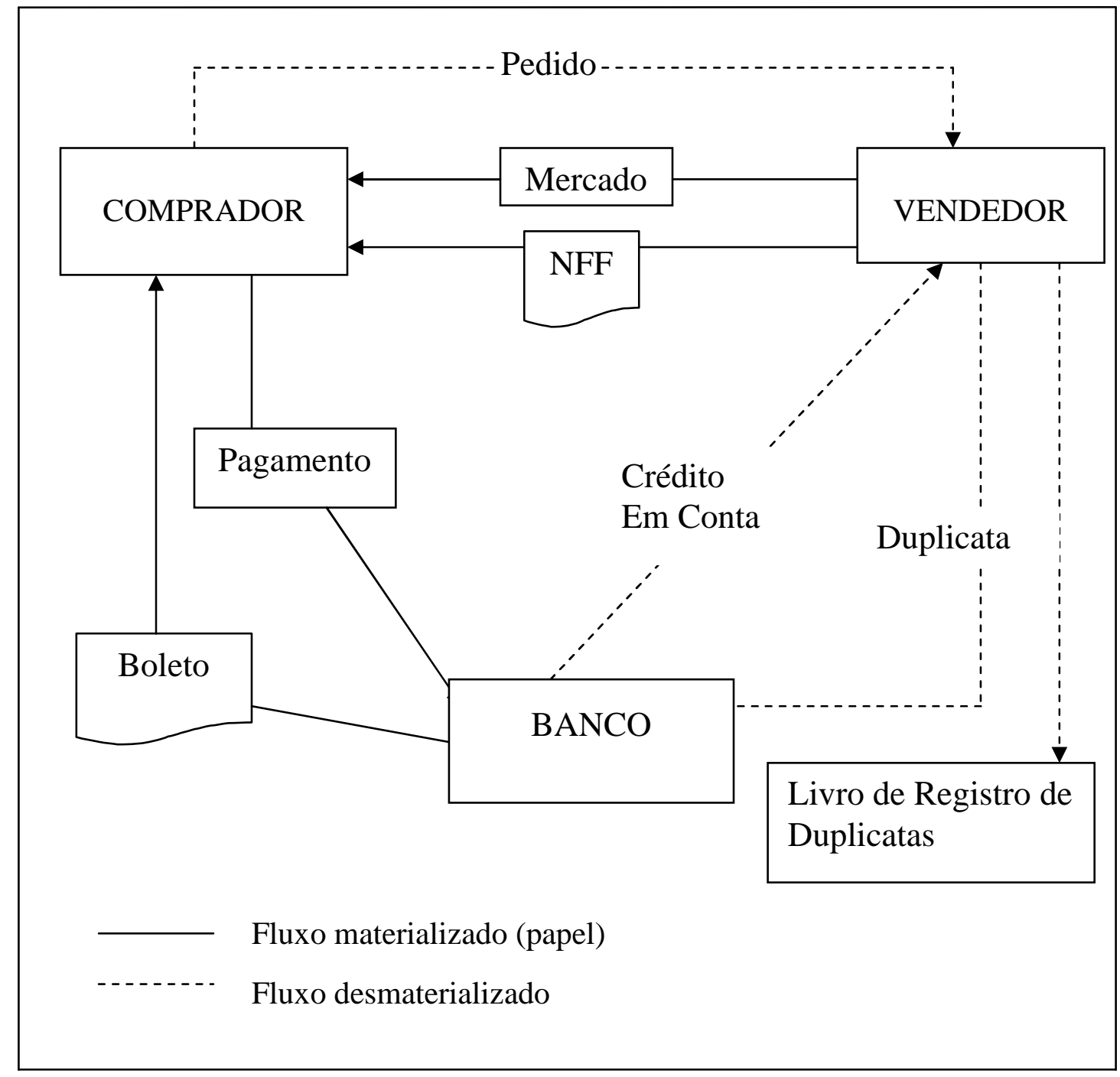

Figura 3

Ademais, os protocolos de EDI bancário prevêem, além das informações que caracterizam a duplicata (nome e domicílio do devedor, número da fatura, valor do título, data de vencimento, etc.), o envio de instruções especiais de cobrança, tais como, prorrogação da data de vencimento, taxa dos juros moratórios, desconto especial por antecipação e outros. Uma dessas instruções pode ser o número de dias de tolerância que o credor concede ao devedor, após o vencimento do pagamento, antes de 
remeter o título a protesto (pode ser dia nenhum). Então, transcorridos esses dias de tolerância após o vencimento, se não houve o pagamento, o banco encaminha a duplicata para protesto. O cartório, por sua vez, notifica o devedor para pagar, e, não havendo o pagamento, é lavrado o protesto, na forma da lei, que regulamenta os serviços de protesto de títulos (Lei 9.492/97). Com o instrumento de protesto, o credor poderá instruir processo executivo.

Ressalta-se que o banco não possui a duplicata materializada em papel. Então, conforme representado na Figura 4, ele simplesmente envia "indicações" suficientes para caracterizar o título. Nas grandes comarcas, os cartórios estão aparelhados para receber essas indicações por EDI.

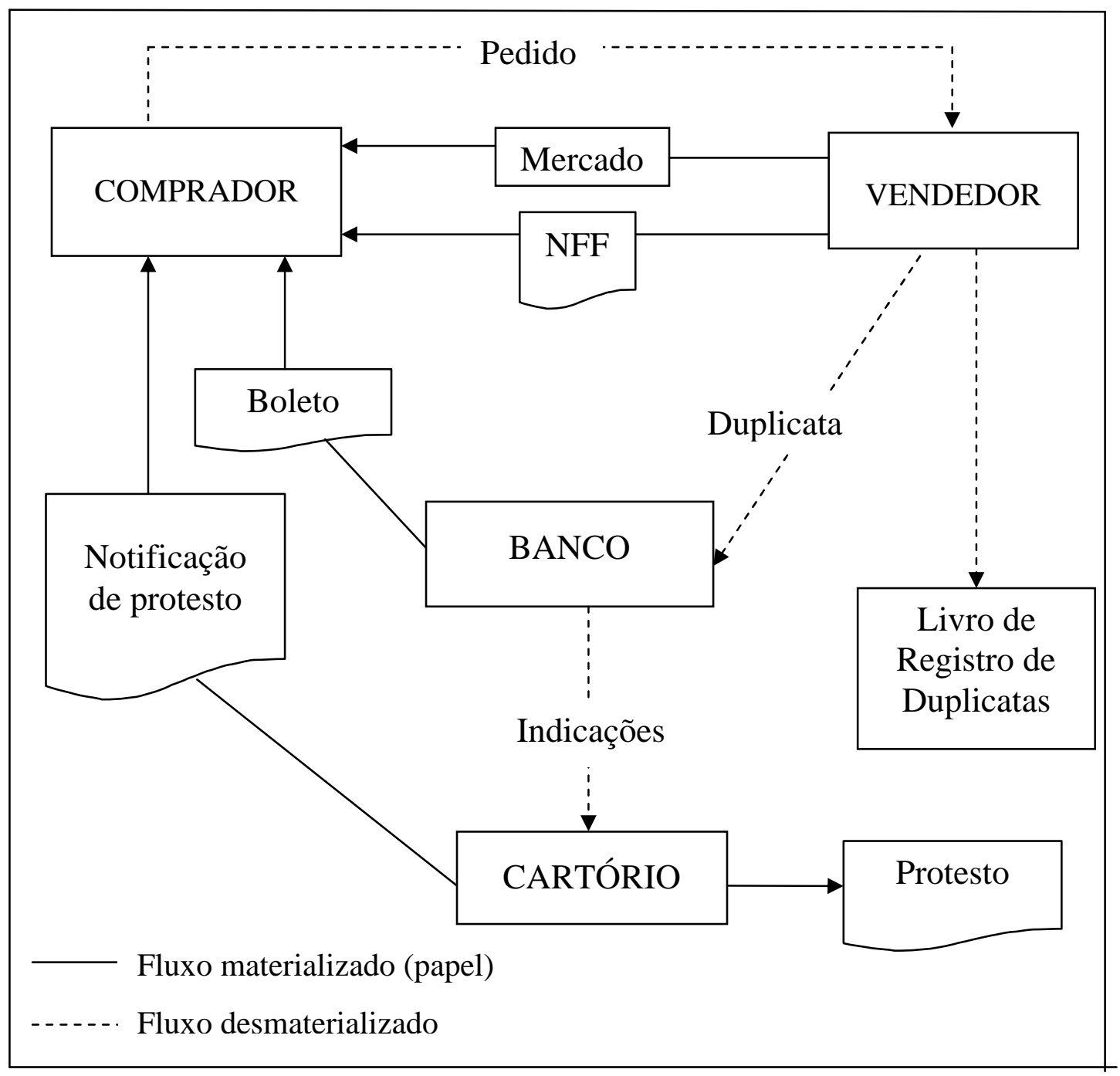

Figura 4 
O protesto de duplicatas virtuais e a sua conseqüente execução será objeto de análise no subitem IV.5. Por ora, cabe observar que o protesto de duplicatas mercantis e de prestação de serviços, a partir de indicações transmitidas por meio magnético ou de gravação eletrônica de dados, está previsto expressamente na Lei 9.492/97, art. $8^{\circ}$, parágrafo único. Veja-se:

\begin{abstract}
“Art. $\mathbf{8}^{\circ}$ Os títulos e documentos de dívida serão recepcionados, distribuídos e entregues na mesma data aos Tabelionatos de Protesto, obedecidos os critérios de quantidade e qualidade.

Parágrafo único. Poderão ser recepcionadas as indicações a protestos das Duplicatas Mercantis e de Prestação de Serviços, por meio magnético ou de gravação eletrônica de dados, sendo de inteira responsabilidade do apresentante os dados fornecidos, ficando a cargo dos Tabelionatos a mera instrumentalização das mesmas" (grifamos)
\end{abstract}

Não obstante, e como já mencionado anteriormente, o Código Civil em seu art. $887, \S 3^{\circ}$, diz que:

" $\$ 3^{\circ} \mathrm{O}$ título poderá ser emitido a partir dos caracteres criados em computador ou meio técnico equivalente e que constem da escrituração do emitente, observados os requisitos mínimos previstos neste artigo."

FÁBIO ULHOA COELHO corrobora o modelo apresentado, afirmando que, no Brasil, a prática do saque de duplicatas virtuais é uma realidade, que permite às empresas informatizar por completo a administração do crédito concedido. Sustenta também que, graças aos institutos do aceite por presunção, do protesto por indicações e da execução de duplicata não assinada, "o direito brasileiro, independente de qualquer alteração legislativa, já ampara a executividade de duplicata virtual, isto é, de título constituído, negociado e protestado exclusivamente em meios magnéticos" $" 53$.

\footnotetext{
${ }^{53}$ COELHO, Fábio Ulhoa. Curso de Direito Comercial, $5^{\text {a }}$ ed. São Paulo: Saraiva, 2001. v 01. p. 457.
} 
Conforme se verá mais adiante, esse posicionamento de FÁBIO ULHOA COELHO não é pacífico, ao contrário, encontra muitas opiniões divergentes na doutrina e na jurisprudência.

Dessa forma, embora a duplicata virtual não seja criada expressamente por lei, ela é lícita, válida e eficaz, visto que não fere nenhum dispositivo legal. Assim, pode-se dizer que a duplicata virtual fere os princípios doutrinários, mas não os princípios legais.

\section{IV.3.1 Caracterização da duplicata virtual}

Vistos, de maneira breve, os modelos que representam as práticas de compra e venda mercantil com saque de duplicatas, é possível caracterizar precisamente a duplicata virtual.

A duplicata virtual é a própria duplicata, registrada e mantida exclusivamente em dispositivo informatizado de armazenamento de dados, sob controle do emitente, podendo, potencialmente, ser materializada numa cártula em papel.

A partir dos registros informatizados, o emitente pode remeter, por transferência eletrônica de dados, a duplicata para cobrança. Quando o crédito é satisfeito regularmente no vencimento, a duplicata virtual não chega a ser materializada. Na hipótese de inadimplência, é possível haver o protesto por indicações transmitidas eletronicamente ao cartório. Entretanto, se não for possível essa modalidade de protesto, a duplicata virtual sempre poderá ser impressa em papel pelo emitente.

Ressalta-se que, a duplicata virtual não é uma nova espécie de título de crédito. Ao contrário, a duplicata virtual e a duplicata são o mesmo e 
único título. A qualificação "virtual” provém da condição desmaterializada da duplicata.

Corroborando esta definição, FÁBIO ULHOA COELHO afirma que:

"[...] quando a obrigação registrada por processo informatizado vem a ser satisfatoriamente cumprida, em seu vencimento, ela não chega jamais a ser materializada num título escrito. A sua emissão não se verifica sequer na hipótese de descumprimento do dever pelo adquirente das mercadorias ou serviços, tendo em vista a executividade da duplicata virtual. ${ }^{, 54}$

Já a comprovação da existência da duplicata virtual se dá através do lançamento no Livro de Registro de Duplicatas. Ou seja, se houver um lançamento no Livro de Registro de Duplicatas, o comerciante deve, necessariamente, possuir um registro informatizado correspondente a essa duplicata. Entretanto, se não houver lançamento no Livro de Registro de Duplicatas, não haverá informações constantes de seus computadores capazes de suprir a prova da existência de determinada duplicata.

\section{IV.4. Vantagens e desvantagens da duplicata virtual}

O uso da duplicata virtual tem vantagens e desvantagens de ordem técnica para todas as partes envolvidas.

Para o sacador, a duplicata virtual traz inúmeras vantagens, como, por exemplo, a rapidez no processamento das operações de cobrança, a economia de tempo e de recursos materiais e a segurança contra erros, aliados a enorme redução de custos operacionais.

\footnotetext{
${ }^{54}$ COELHO, Fábio Ulhoa. Curso de Direito Comercial, $5^{\text {a }}$ ed. São Paulo: Saraiva, 2001. v 01. p. 378/379
} 
Já uma das suas desvantagens é em relação ao desconto bancário. Não por sua inaptidão, e sim, por causa da cautela da rede bancária, uma vez que o sistema eletrônico, ainda, não é totalmente seguro.

Para o descontador, que sempre é uma instituição financeira, as vantagens são grandes. Isso porque toda a operação de emissão de boletos, expedição e controle de cobrança e apresentação para protesto é feita pela própria instituição. Dessa forma, com a possibilidade de padronização para todos os clientes, a redução de seus custos operacionais é substancial.

Por outro lado, o sacado é quem fica mais vulnerável no caso de uma duplicata virtual simulada ser apontada para protesto. Neste caso, deve-se tomar muito cuidado, pois em caso de intimação de apontamento em cartório para protesto de duplicata simulada, só resta uma saída para o sacado: a medida cautelar de sustação de protesto.

\section{IV.5. A visão da doutrina na execução das duplicatas virtuais}

Ainda não se encontram muitos doutrinadores dispostos a discorrer sobre a execução das duplicatas virtuais. FÁBIO ULHOA, LUIZ EMYGDIO ROSA JR. e parte da jurisprudência entendem que a duplicata virtual é sim um título executivo. Esses dois juristas, várias vezes citados neste trabalho, examinam a questão com bastante profundidade.

FÁBIO ULHOA COELHO, posiciona-se claramente favorável à viabilidade jurídica do protesto e da execução de duplicatas virtuais. $\mathrm{O}$ trecho reproduzido a seguir resume a posição desse Autor:

"É jurídica, portanto, a execução de duplicata virtual (isto é, nunca papelizada), com a exibição em juízo do instrumento de protesto por indicações e do relatório 
do sistema do credor, que comprova o recebimento das mercadorias pelo sacado.". 55

\title{
LUIZ EMYGDIO ROSA JR. ${ }^{56}$ possui o mesmo entendimento:
}

\begin{abstract}
"Tratando-se de duplicata virtual, entendemos que a conjunção do instrumento de protesto, lavrado por indicações feitas no meio magnético ou de gravação eletrônica de dados, com a prova da entrega da mercadoria, acrescida do fato do sacado não ter dado expressamente as razões da recusa do aceite, constitui título executivo extrajudicial por força do $\$ 2^{\circ}$. do art. 15 da LD e do inciso VII do art. 585 do CPC. A única diferença para o título executivo referido no $\$ 2^{\circ}$. do art. $2^{\circ}$. da $\mathrm{LD}$, reside em que na duplicata virtual o protesto é feito mediante indicações por meio magnético ou registro eletrônico de dados, e não mediante papel. Como se pode observar, a própria $L D$, no $\$ 2^{\circ}$. do art. 15 , dispensa a cártula para a execução do crédito decorrente de uma situação jurídica preexistente (compra e venda mercantil), e, assim, a ausência da cártula, do papel, não tem condão de impedir a execução do crédito decorrente da compra e venda mercantil ou de prestação de serviços."
\end{abstract}

Esse entendimento é muito relevante, já que pode implicar na obtenção do valor correspondente, em razão da inadimplência de uma duplicata, muito mais rapidamente, visto que o processo de execução é, dentre todos os processos do Brasil, um dos mais céleres.

A outra opção de ação proposta para aqueles que entendem que a duplicata virtual não é um título executivo, é a ação de cobrança, como cita AMADOR PAES DE ALMEIDA 57 , "na ocorrência de inadimplemento do devedor, não ensejará a 'duplicata escritural' processo de execução, não facultando senão a cobrança ordinária"

Sabe-se que o Código de Processo Civil estabelece que a duplicata é um título executivo extrajudicial (art. 585, I do $\mathrm{CPC}^{58}$ ). A Lei 5.474/68, por

\footnotetext{
${ }^{55}$ COELHO, Fábio Ulhoa. Curso de Direito Comercial, $5^{\mathrm{a}}$ ed. São Paulo: Saraiva, 2001. v 01. p. 459

${ }^{56}$ ROSA JUNIOR, Luiz Emygdio Franco da. Op. cit., p. 755-756.

${ }^{57}$ ALMEIDA, Amador Paes de. Teoria e prática dos títulos de crédito. $23^{a}$. ed. São Paulo: Saraiva, 2004. p. 220.

${ }_{58}$ Art. 585. São títulos executivos extrajudiciais:

I - a letra de câmbio, a nota promissória, a duplicata, a debênture e o cheque;
} 
sua vez, estabelece os requisitos para que o crédito representado pela duplicata possa ser exigido por processo de execução (art. 15 da $\mathrm{LD}^{59}$ ).

Assim, a execução da duplicata, contra o devedor principal, depende da modalidade de aceite que foi praticado.

Se a execução se dirige contra o avalista do sacado, o credor deve exibir o título onde consta o aval, sendo dispensável o protesto. Já, contra os endossantes e respectivos avalistas, além da apresentação do título que demonstre o endosso e o aval, é necessário o protesto, tirado em até trinta dias a partir do vencimento (art. $15, \S 1^{\circ}, \mathrm{c} / \mathrm{c}$ art. $13, \S 4^{\circ 60}$. da LD).

Retornando à duplicata virtual, deve-se lembrar que, como não há cártula, ocorre o aceite presumido e a mesma é levada a protesto por indicações a partir do boleto bancário. Supondo-se que tenha sido possível o protesto nessas condições, a execução se dará na modalidade prevista no art. 15, II, da Lei das Duplicatas, conforme autorizado pelo $\S 2^{\circ}$, do mesmo dispositivo legal.

\footnotetext{
${ }^{59}$ Art 15 - A cobrança judicial de duplicata ou triplicata será efetuada de conformidade com o processo aplicável aos títulos executivos extrajudiciais, de que cogita o Livro II do Código de Processo Civil,quando se tratar:

1 - de duplicata ou triplicata aceita, protestada ou não;

II - de duplicata ou triplicata não aceita, contanto que, cumulativamente:

a) haja sido protestada;

b) esteja acompanhada de documento hábil comprobatório da entrega e recebimento da mercadoria; $\mathrm{e}$

c) o sacado não tenha, comprovadamente, recusado o aceite, no prazo, nas condições e pelos motivos previstos nos arts. $7^{\circ}$ e $8^{\circ}$ desta Lei.

$\$ \mathbf{1}^{\mathbf{o}}$ - Contra o sacador, os endossantes e respectivos avalistas caberá o processo de execução referido neste artigo, quaisquer que sejam a forma e as condições do protesto.

$\$ \mathbf{2}^{\mathbf{o}}$ - Processar-se-á também da mesma maneira a execução de duplicata ou triplicata não aceita e não devolvida, desde que haja sido protestada mediante indicações do credor ou do apresentante do título, nos termos do art. 14, preenchidas as condições do inciso II deste artigo.

${ }^{60}$ Art. 13. A duplicata é protestável por falta de aceite de devolução ou pagamento $\$ 4^{\circ} \mathrm{O}$ portador que não tirar o protesto da duplicata, em forma regular e dentro do prazo de 30 (trinta) dias, contado da data de seu vencimento, perderá o direito de regresso contra os endossantes e respectivos avalistas
} 
Ocorre que, além dos requisitos apresentados no art. 15, II, da LD alguns Juízes têm exigido a apresentação da cártula. Essa exigência é criticada com veemência por FÁBIO ULHOA COELHO:

\begin{abstract}
“A propósito dessa última hipótese, prevista no art. $15, \S 2^{\circ}$, da $\mathrm{LD}$, deve-se criticar a exigência, feita por alguns juízes, de exibição da duplicata, mesmo quando o protesto se efetivou por indicações do credor. Na verdade, trata-se de mera formalidade, por tudo dispensável. A emissão da duplicata em papel, apenas para ser juntada aos autos da execução, quando já apresentado o instrumento de protesto por indicações e o comprovante do recebimento das mercadorias, não tem nenhum sentido." 61
\end{abstract}

Mesmo que não haja nenhuma exigência adicional, a lei é clara quanto aos três requisitos para constituição do título executivo: (i) o protesto; (ii) a prova da entrega e do recebimento da mercadoria, e (iii) a não recusa do aceite.

E é nesse sentido que LUIZ EMYGDIO ROSA JR. ${ }^{62}$ se manifesta:

"Assim, se o mencionado dispositivo legal está posicionado no Capítulo I (Disposições Gerais) do Título VIII (Títulos de Crédito), não pode pairar mais dúvida de que o título virtual, desde que preencha os requisitos mínimos previstos na Lei $n^{0} 5.474 / 68$ e os seus caracteres gerais constem da escrituração do emitente, corresponderá a título executivo extrajudicial"

Cabe aqui tecer um comentário sobre as alternativas de que dispõe o credor de uma duplicata virtual, caso se considere impossível, juridicamente, a constituição do título executivo extrajudicial.

A lei prevê que, quando a duplicata ou triplicata não preenche os requisitos para constituição do título executivo extrajudicial, previstos no art. 15, o credor deve recorrer ao procedimento ordinário (art. 16 da $\mathrm{LD}^{63}$ ).

\footnotetext{
${ }^{61}$ COELHO, Fábio Ulhoa. Op.cit., p. 455.

${ }^{62}$ ROSA JUNIOR, Luiz Emygdio Franco da. Op. cit., p. 757-758.

63 Art. 16 - Aplica-se o procedimento ordinário previsto no Código de Processo Civil à ação do credor contra o devedor, por duplicata ou triplicata que não preencha os requisitos do art. 15, incisos l e II, e $\S \S 1^{\circ}$ e $2^{\circ}$, bem como à ação para ilidir as razões invocadas pelo devedor para o não aceite do título, nos casos previstos no art. $8^{\circ}$.
} 
AMADOR PAES DE ALMEIDA ${ }^{64}$, por exemplo, vê no procedimento ordinário a única saída para o credor de uma duplicata não materializada.

Há, ainda, quem entenda ser possível o ajuizamento de ação monitória, onde o boleto bancário é o documento que instrui a ação.

A diferença entre a ação de execução e a ação de cobrança é grande, a começar pelo tipo de processo, sendo a primeira regulada no Livro II (Processo de Execução) e a segunda no Livro I (Processo de Conhecimento), ambos do Código de Processo Civil.

Enquanto na ação de conhecimento é necessário provar a relação jurídica e discutir o mérito da questão, para, assim, se chegar a um título executivo judicial, no processo de execução, já se tem o título executivo em mãos. Nesse caso, não há discussão do mérito e o mandado de citação ${ }^{65}$ do devedor é para o mesmo realizar o pagamento ou nomear bens à penhora, o que já é bem mais coercitivo, até por isso é chamada de Execução Forçada.

Já as diferenças entre a ação monitória e a ação de execução de título extrajudicial, não são tantas, mas é válida a observação, pois se não existissem diferenças, não seriam duas ações diversas. A ação monitória, prevista no Capítulo XV, Título II, do Livro IV do Código de Processo Civil, em seu art. 1.102a, expressa o seguinte:

\footnotetext{
"Art. 1.102a. A Ação monitória compete a quem pretender, com base em prova escrita sem eficácia de título executivo; pagamento de soma em dinheiro, entrega de coisa fungível ou de determinado bem móvel"
}

64 ALMEIDA, Amador Paes de. Op. cit., p. 185.

65 Art. 652. O executado será citado para, no prazo de 3 (três) dias, efetuar o pagamento da dívida.

$\S 1^{\circ}$ Não efetuado o pagamento, munido da segunda via do mandado, o oficial de justiça procederá de imediato à penhora de bens e a sua avaliação, lavrando-se o respectivo auto e de tais atos intimando, na mesma oportunidade, o executado. 
Dessa forma, a ação monitória, frente à ação de cobrança pelo rito ordinário, é muito mais célere, no entanto, na monitória, compete ao Autor juntar prova escrita, que não tenha validade de título executivo, pois este tornar-se-á um novo título.

Assim, para aqueles que entendem que a duplicata virtual não é um título de crédito executivo, essa seria a maneira de se obter o crédito, no caso da inadimplência da obrigação.

Como mencionado, FÁBIO ULHOA COELHO ${ }^{66}$, discorda dessa opinião, defendendo que a duplicata possui todos os requisitos para ser considerada um título executivo, inclusive, previsão legal:

"O direito em vigor dá sustentação, contudo à execução da duplicata 'virtual' porque não exige a sua exibição em papel, como requisito para liberar a prestação jurisdicional satisfativa".

Por fim, FÁBIO ULHOA COELHO complementa seu entendimento, alegando que, "em juízo basta a apresentação de dois papéis: o instrumento de protesto por indicações e o comprovante de entrega das mercadoria "67.

\footnotetext{
${ }^{66}$ COELHO, Fábio Ulhoa. Op.cit., p. 458.
}

${ }^{67}$ COELHO, Fábio Ulhoa. Op.cit., p. 459. 


\section{V - Conclusão}

Como vimos, a temática dos títulos de crédito eletrônicos envolve questões amplas, que vão desde a sua criação, por meio eletrônico, até a sua validade, aceite e execução. Isso, sem contar com o avanço da informática, ponto de convergência do presente tema, junto com o Direito e a Economia.

Sabe-se que a economia se beneficia pelo crédito exatamente pela possibilidade da sua ampla circulação, o que acaba por afastar a necessidade imediata de disponibilização de moeda para a realização de operações mercantis.

Com o surgimento dos títulos de créditos eletrônicos, originados e formados no ambiente eletrônico, passou-se a indagar-se a seguinte pergunta: " $E$ possível sustentar a natureza jurídica de títulos de créditos a esses documentos gerados no ambiente eletrônico, e que, por isso, apresentam-se desmaterializados do documento de papel?"

Primeiramente, a desmaterialização não descaracteriza um título de crédito. Isso porque, a falta do suporte em papel não impede a incorporação do direito em um documento gerado pelo meio eletrônico, que dotado de autonomia e literalidade, é capaz de circular, promovendo, assim, a principal finalidade dos títulos de crédito.

Sem contar que, um documento eletrônico, assinado digitalmente, conforme diretrizes da Medida Provisória 2.200/01, se equipara aos documentos físicos, passando a seguir as mesmas regras existentes para eles.

Ressalta-se que, foi diante das necessidades impostas por um mundo cada vez mais globalizado e informatizado, onde o tempo é cada vez mais escasso, que se exigiu o desenvolvimento de instrumentos que atendessem as expectativas do 
mercado, instrumentos estes que foram criados face ao surgimento das modernas tecnologias desenvolvidas pela informática.

Assim, se um título, mesmo que na forma eletrônica, desempenhar a sua finalidade, que é promover a circulação de riquezas, a ausência da cártula não tem força suficiente para afastar as características próprias dos títulos de crédito.

Quanto à necessidade ou não de uma legislação específica para regular as operações realizadas no ambiente eletrônico, essa questão é continua sendo bastante polêmica, tendo em vista que parte da doutrina defende que a simples interpretação da legislação vigente seria suficiente para abrigar a utilização dos títulos de créditos eletrônicos, enquanto outros, alegam que a legislação atual não é suficiente para englobar as novas práticas mercantis.

A questão de fato gera grandes discussões, porém, resta claro que existe sim uma necessidade da criação de novas leis para regulamentar os negócios informatizados, inclusive os firmados através dos títulos de crédito.

Isso porque a interpretação da legislação vigente, com o uso dos princípios gerais de direito, como a analogia e a equidade, não é capaz de conceder ao comércio eletrônico a segurança que o mesmo necessita. Mesmo porque, a união entre a informática e o Direito Comercial pode gerar diversas situações únicas, que demandam normas específicas.

Um bom exemplo é o caso da duplicata virtual, analisada no Capítulo IV, que ainda se baseia, principalmente, no fator confiança.

Deve-se, ainda, lembrar, que vários países já buscaram adequar a sua legislação ao comércio eletrônico, demonstrando, assim, a real necessidade da existência de um regulamento específico para tais relações comerciais. 
Porém, o Brasil já está no caminho certo, buscando sanar as lacunas existentes através de Projetos de Leis, que visam regulamentar o comércio eletrônico e a assinatura digital.

Por fim, conclui-se que, apesar da existência de uma carência na legislação vigente, certo é que o Código Civil trouxe inovações muito benéficas, que aceleraram certamente o processo para a legalização dos títulos de créditos eletrônicos, pois trouxe em seu corpo a contemplação do mundo virtual, algo que era impossível de se ter no Código Civil de 1916. 


\section{VI - Bibliografia}

ALMEIDA, Amador Paes de. Teoria e prática dos títulos de crédito. 23ª . ed. São Paulo: Saraiva, 2004. 574 p.

BARBOSA, Lucio de Oliveira. Duplicata Virtual - Aspectos Controvertidos. São Paulo: Memória Jurídica, 2004. 151 p.

BORBA, Gustavo Tavares. A desmaterialização dos títulos de crédito. Disponível em <http://www.borbaadvogados.com.br/public5.pdf>. Acesso em 16 maio 2009.

BULGARELli, Waldiro. Títulos de Crédito: Direito Comercial III. 1ª ed. São Paulo: Atlas S.A., 1979. 506 p.

COELHO, Fábio Ulhoa. Curso de Direito Comercial, $5^{\text {a }}$ ed. São Paulo: Saraiva, 2001. v 01. $491 \mathrm{p}$.

Manual de Direito Comercial. 20ª ed. São Paulo: Saraiva, 2008. 497

p.

Títulos de Crédito Eletrônicos. Revista dos Advogados, São Paulo, no. 96, p. 41-47, mar. 2008.

COVAS, Silvânio. O contrato no ambiente virtual. Contratação por meio da informática. Revista de Direito Bancário e de Mercado de Capitais. São Paulo: Revista dos Tribunais, ano 02, n. 05, p. 100-122. maio/ago. 1999.

LEVY, Pierre. O que é virtual? Disponível em < http://books.google.com.br.>. Acesso em 03 maio 2009. 
LUCCA, Newton de. Títulos e Contratos Eletrônicos: O advento da Informática e seu impacto no mundo jurídico. In: LUCCA, Newton de; SIMÃO FILHO, Adalberto (Org.). Direito \& Internet. $1^{\text {a }}$ reimp. São Paulo: EDIPRO, 2000. p.21100.

MARCANCINI, Augusto Tavares Rosa. O documento eletrônico como meio de prova. Revista da Associação Brasileira de Propriedade Industrial (ABPI), São Paulo, n.058, p. 003-023, maio/jun. 2002.

MARTINS, Fran. Títulos de crédito. $13^{\mathrm{a}}$ ed. Rio de Janeiro: Forense, 2002. vol. $01.360 \mathrm{p}$.

MIRANDA, Francisco Cavalcanti Pontes de. Tratado de Direito Cambiário.

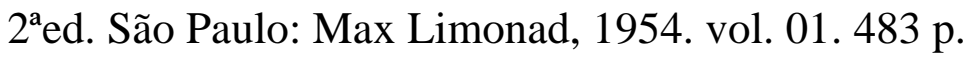

Comentários ao Código Civil, $3^{\mathrm{a}}$ ed. Rio de Janeiro: Forense, 1996. tomo IV. 524 p.

MIRANDA, Maria Bernardete. O Título de Crédito Eletrônico no novo Código Civil. Disponível em

$<$ http://www.saraivajur.com.br/menuEsquerdo/doutrinaArtigosDetalhe.aspx?Dou trina=270>. Acesso em 01 maio 2009.

QUEIROZ, Regis Magalhães Soares de; FRANÇA, Henrique de Azevedo Ferreira. A assinatura digital e o tabelião virtual. In: LUCCA, Newton de; SIMÃO FILHO, Adalberto (Org.). Direito \& Internet. $1^{\text {a }}$ reimp. São Paulo: EDIPRO, 2000. p. 371-418.

ROSA JUNIOR, Luiz Emygdio Franco da. Títulos de Crédito. $5^{\mathrm{a}}$ ed. Rio de Janeiro: Renovar, 2007. 784 p. 
REQUIÃO, Rubens Edmundo. Curso de Direito Comercial. 26a ed. São Paulo: Saraiva, 2009. v. 02.762 p.

SILVA, Marcos Paulo Félix da. Títulos de Crédito no Código Civil de 2002. Curitiba: Juruá, 2009. 175p.

VOLPI, Marlon Marcelo. Assinatura Digital - Aspectos Técnicos, Práticos e Legais. Rio de Janeiro: Axcel Books do Brasil, 2001. 142 p.

WALD, Arnoldo. Um novo direito para uma nova economia. In GRECO, Marco Aurélio; MARTINS, Ives Gandra da Silva (Org.). Direito e Internet: relações jurídicas na sociedade informatizada. São Paulo: RT, 2001. p. 9-30. 